\title{
Research Paper \\ Comparison of the Effectiveness of Positive Parenting Program and Parental Management Training on the Improvement of Parent-Child Relationship
}

\author{
Khadijeh Hatamifar $^{1}$, Hossein Zare ${ }^{* 2}$, Mansoureh Shahryari Ahmadi ${ }^{3}$
}

1. Ph.D. Studentd of Educational Psychology, Central Tehran Branch, Islamic Azad University, Tehran, Iran

2. Professor, Department of Psychology, Faculty of Educational Sciences and Psychology, Payam Noor University, Tehran, Iran 3. Assistant Professor, Department of Psychology of Exceptional Children, Central Tehran Branch, Islamic Azad University, Tehran, Iran

Citation: Hatamifar K, Zare H, Shahryari Ahmadi M. Comparison of the effectiveness of positive parenting program and parental management training on the improvement of parent-child relationship. Quarterly Journal of Child Mental Health. 2020; 7(3): 25-39.

\section{http://dx.doi.org/10.52547/jemh.7.3.4}

\section{A R T I C L E I N F O}

\section{Keywords:}

Positive parenting, parental management, parent-child relationship

Received: 2 Jun 2020

Accepted: 19 Sep 2020

Available: 7 Dec 2020

\section{A B S T R A C T}

Background and Purpose: Parent-child relationship plays an important role in the vulnerability and flexibility of children. Different methods have been used in clinical studies to improve the parentchild relationship. This study aimed to compare the effectiveness of positive parenting program and parental management on parent-child relationship.

Method: This research was a pretest-posttest quasi-experimental study with one-month follow-up. The study population included the parents of all the female primary school students with behavioral problems in Dist. 1 of Tehran during the academic year of 2019-2020. Among them, a sample of 45 parents were selected and then randomly assigned to one of the three groups (two experimental groups and one control group) (i.e. 15 per group). The groups completed the Child-Parent Relationship Scale (Pianta, 1994) at all the three stages. The experimental groups received eight 90min positive parenting program and twelve 12-min sessions of parental management training, while the control group underwent no intervention.

Results: Results of multivariate analysis of covariance (MANCOVA) showed that the groups were significantly different in the components of parent-child relationship. Both interventions were effective on the improvement of parent-child relationship (closeness: $\mathrm{P}<.01, \mathrm{~F}=12.01$; dependence: $\mathrm{P}<.01, \mathrm{~F}=19.92$; conflict: $\mathrm{P}<.01, \mathrm{~F}=37.37$ ) and showed equal effectiveness on parent-child relationship.

Conclusion: The research findings showed both methods have the necessary efficiency to improve the parent-child relationship but in parental management training in the follow-up phase, lack of coordination and interaction between parents in dealing with the child and motivation and instability of mothers in the skillful use and continuous of educational methods, has reduced the parent-child relationship.

\footnotetext{
* Corresponding author: Hossein Zare, Professor, Department of Psychology, Faculty of Educational Sciences and Psychology, Payam Noor University, Tehran, Iran.

E-mail addresses: h_zare@pnu.ac.ir
}

2476-5740/ (C) 2019 The Authors. This is an open access article under the CC BY-NC-ND license (https://creativecommons.org/licenses/by-nc-nd/3.0/). 


\section{مقايسه اثربخشى آموزش والدكرى مثبت و مديريت والدين بر بهبود رابطه والد - كود كى}

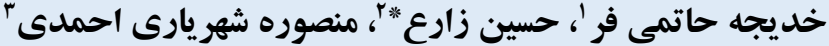

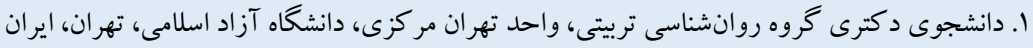

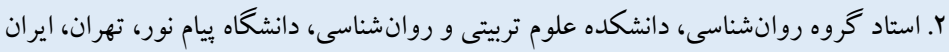

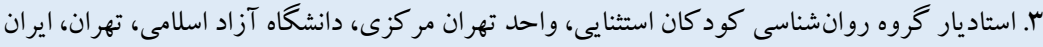

زمينه و هدف: رابطه والد-كودكك نقش مهمى در آسيبذيذى يا سلامت روانشناختى كودكان دارد. روشهاى مختلفى در مطالعات

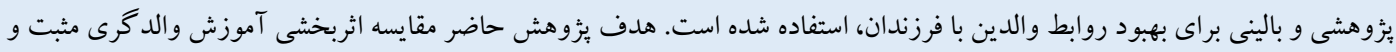

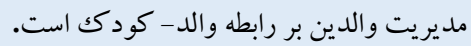

روش: روش ئوهش، نيمه آزمايشى باطرح ييش آزمون- يُس آزمون و ييخيرى يككماهه بود. جامعه آمارى شامل تمامى والدين دانش آموزان

مشخصات مقاله

\section{كليدواثهها:}

والدكرى مثبت،

مديريت والدين،

رابطه والد - كودكى

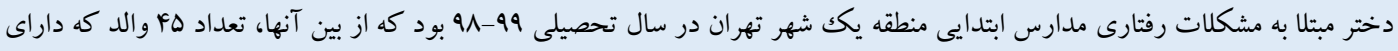

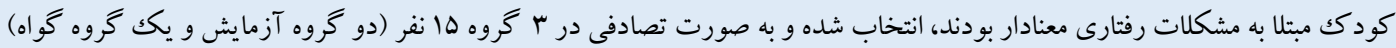

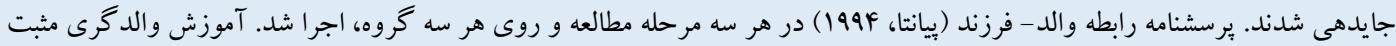

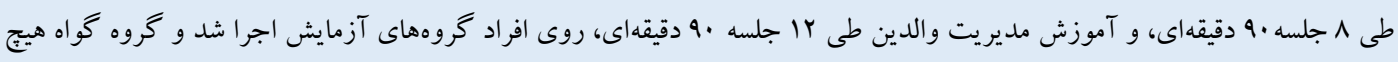
مداخلهاى دريافت نكردند. يافته ها: نتايج تحليل كوواريانس جندمتغيرى نشان داد كه بين سه گروه در مؤلفهاى رابطه والد-كودكك، تفاوت معنادار وجود دارد. هر

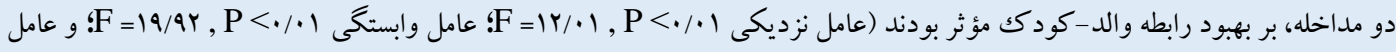

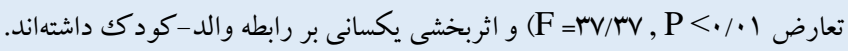

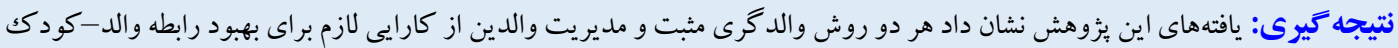

دريافت شده: بr/

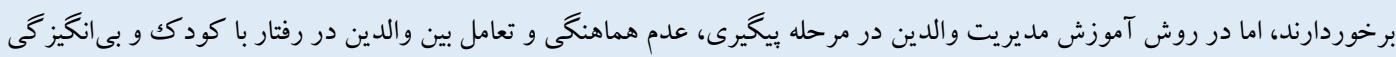

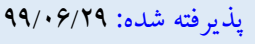
و بى ثباتى مادران در استفاده ماهر انه و مداوم از روشهاى آموزشى، سبب كاهش رابطه والد-كودك شك شده است. منتشر شده: 99//PV

* نويسنده مسئول: حسين زارع، استاد گروه روانشناسى، دانشكده علوم تربيتى و روانشناسى، دانشگاه يِيام نور، تهران، ايران. رايانامه: h_zare@pnu.ac.ir 
يزّوهش زابلو تسـكـى، بر ادشـو و اسـتوارت، كيفيـت روابط والدين به خصـوص رابطه مـادر -كود كى، نقش تعيين كنندهاى در ســلامت روان كود كك داشته و تأثير طولانى آن بر كودكك تأييد شده است (V).

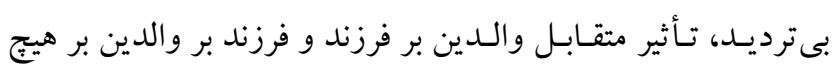

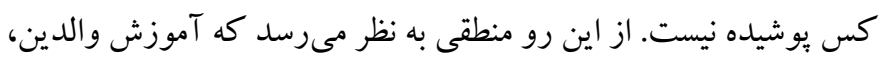

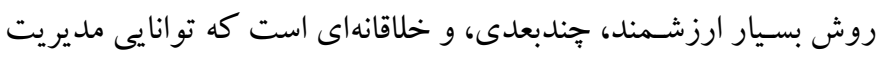

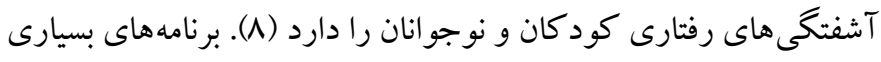

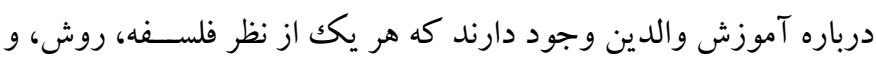

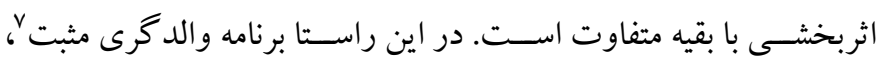

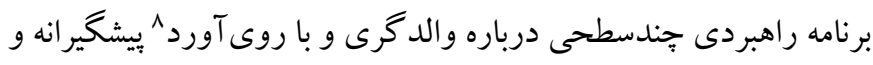

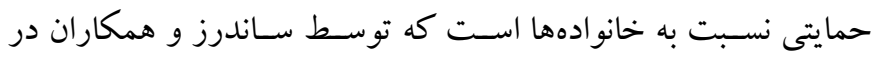

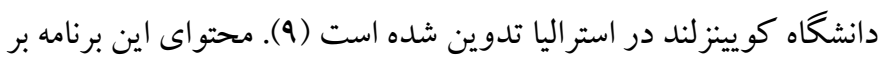
اسـاس مدل ياد گيرى اجتماعى اسـت كه تعامل والد - كود كك و ماهيت

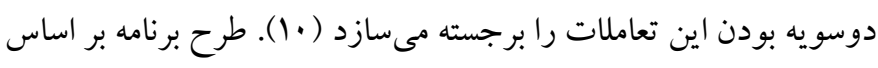

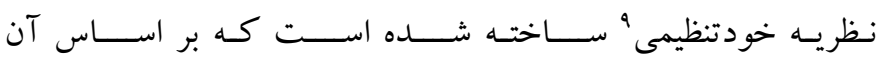

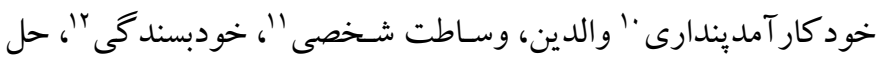

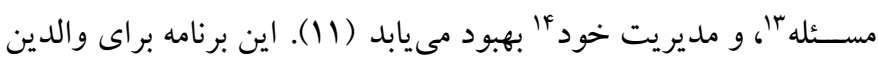

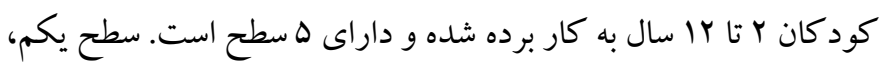
شـامل اطلاعرسـانى عمومى اسـت كه از طريق رسانها براى همه والدين

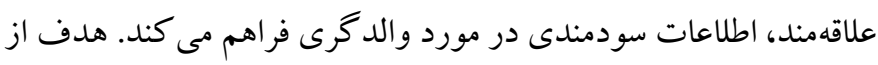

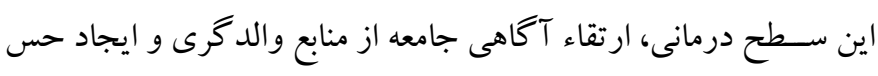

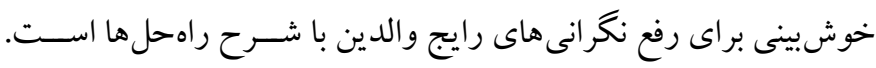

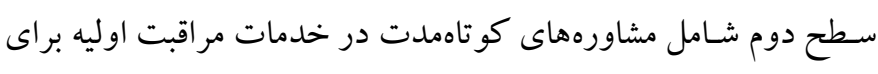
مشكلات خفيف رفتارى است كه در دو جلسه درمانى به منظور بيشخيرى

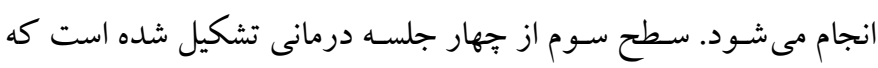

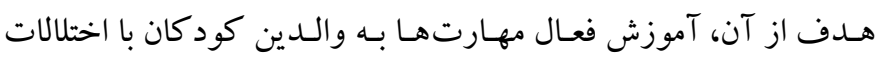
خفيف و متوسط رفتارى است. سطح جهارم، ده جلسه آموزش فردى يا

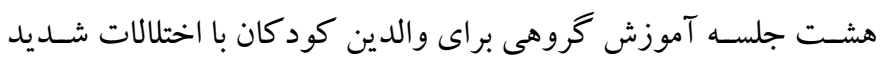

\section{Approach}

9. Self- regulatory theory

10. Self-efficacy

11. personal mediation

12. Self- sufficiency

13. Problem solving

14. Self-management

\section{مقدمه}

عامل بنيادين شـكل گيرى رابطه فرد با خود و ديخران، تجربههاى فرد در

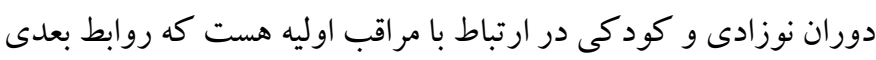

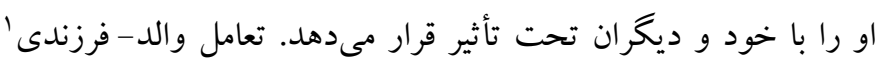
نخستين معرف دنياى ارتباطات كودكك و رابطه مهم و حياتى براى ايجاد

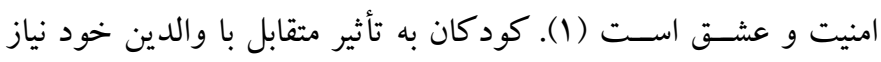

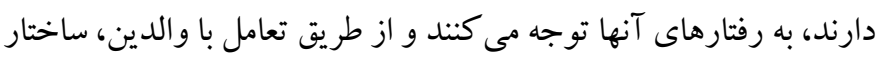

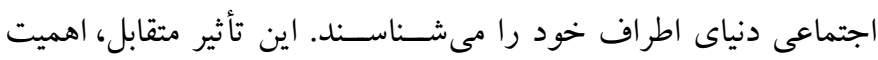

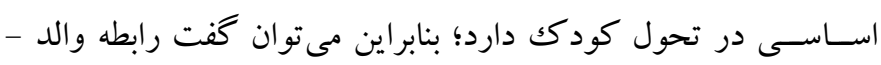

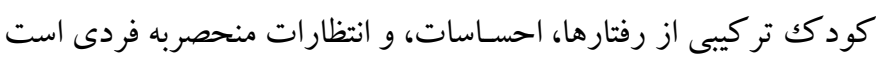

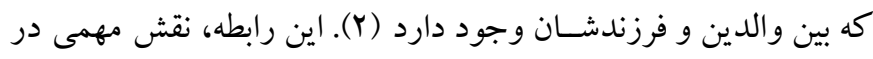

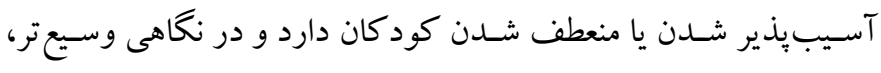

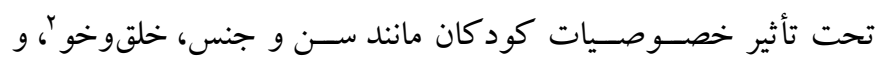
وضعيت زيستـشـناختى كود كك قرار مى گيرد و در كنار خصـوصيات

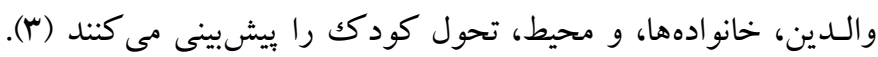

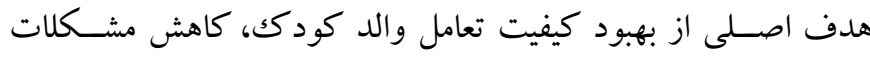
رفتارى كودكك و افزايش رفتارهاى موافق اجتماعى، بهبود مهارتهات بهاى

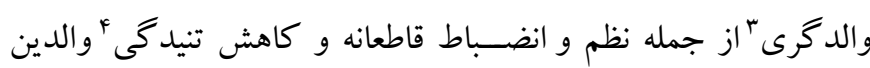

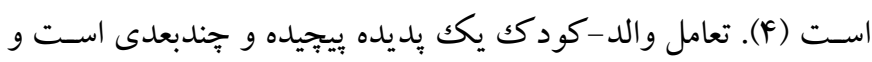

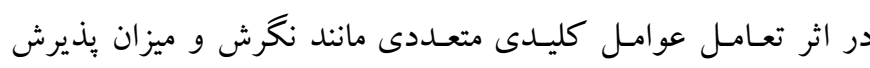

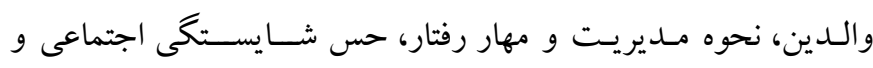

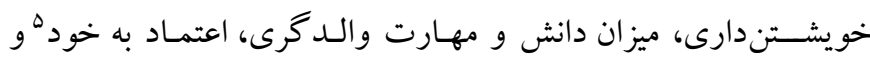

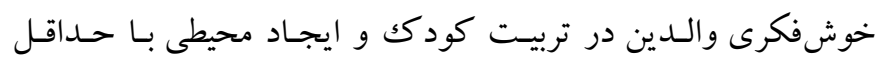

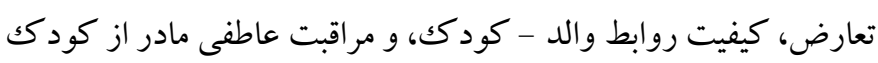

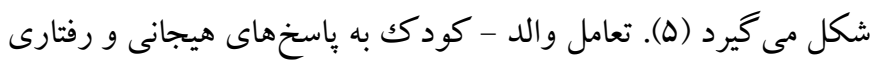

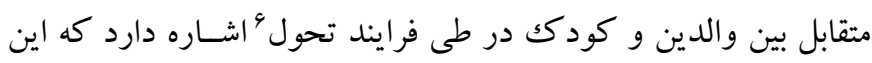

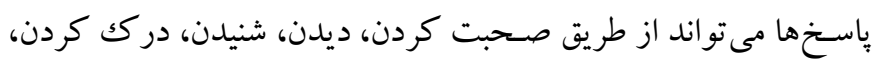
در دسـترس بودن، و سـاير روشهاى برقرارى ارتباط باشــــ (9). در

1. Parent-child interaction

2. Character

3. Parenting

4. Stress

5. Self-confidence

6. Development

7. Positive parenting program 
مبتنى بر مدل سـاندرز بر تعامل مادر با كودكك و سـلامت عمومى مادران مبتلا به ديابت نوع يكك بود.

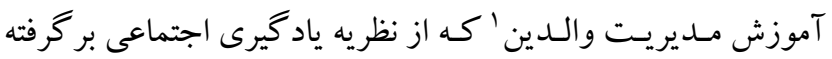
شـده است به منظور مداخله در جرخه اجبارى بين والد و كود كك ايجاد شده است. اين برنامه مداخلهاى، رده سنى بيش دبستانى تا نوجوانى را در

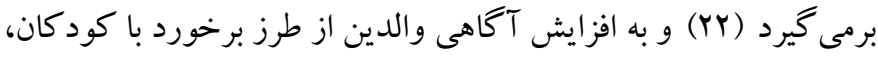
مهارت مهار هيجانات در مقابل رفتار كود كان، كذاشتن قوانين و مقررات

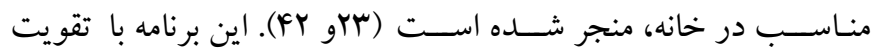
رفتارهاى مثبت، رفتارهاى مطلوب و مناسب كود كك را بيشتر كرده و در بر بره

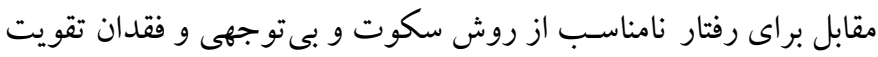

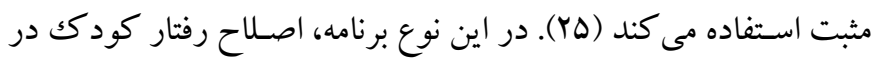
محيط طبيعى منزل توسط والدين و به ويزه مادران كه بيشترين ارتباط را

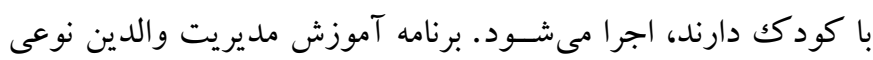

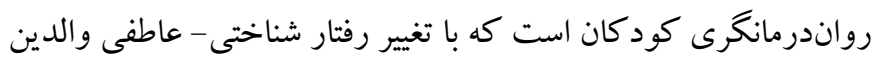

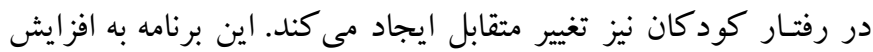

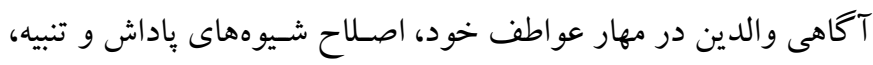

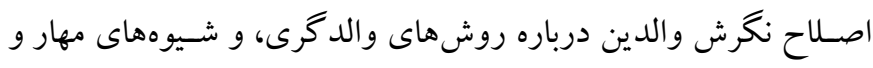

نظارت بر رفتار كودك، منجر مىشود (Y9). نتـايج فراتحليـل در VV مطـالعه مربوط به آموزش مديريت والدين

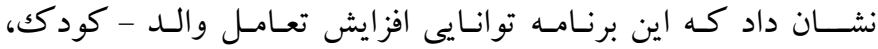

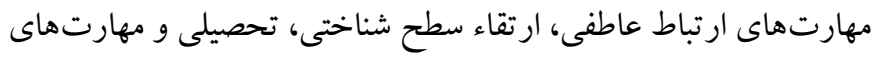
اجتمـاعى كودكك، و همجنين مهارتهـاى حل مسـئله را دارد (VY).

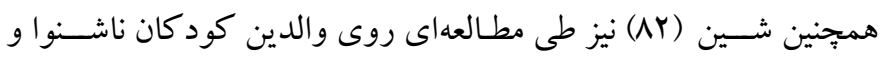

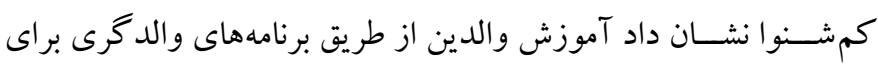

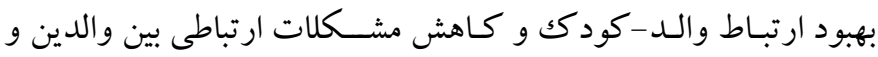
كود كان، مناسـب است. لس و رونان (Ya) با اجراى اين برنامه در مورد

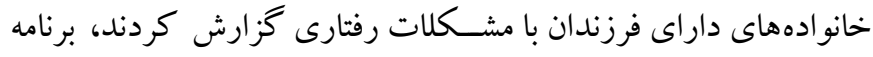

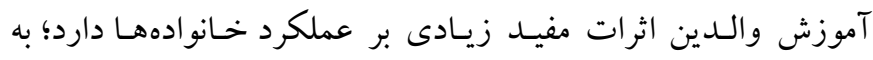

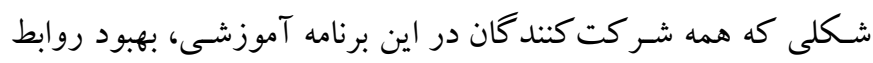

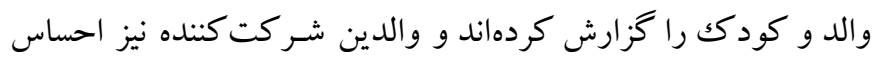

رفتارى است؛؛ و سطح بنجم براى والدينى استفاده مىشـود كه علاوه بر

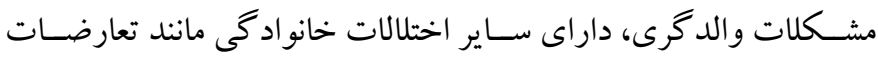

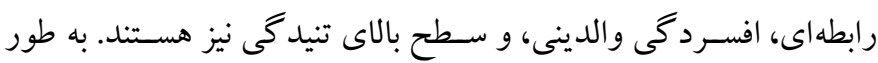

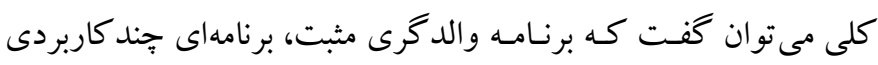

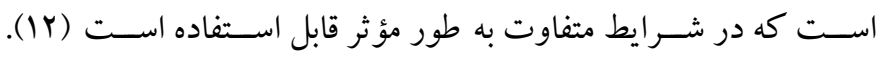

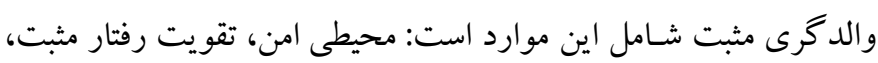

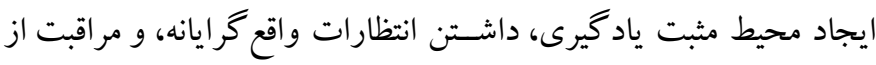

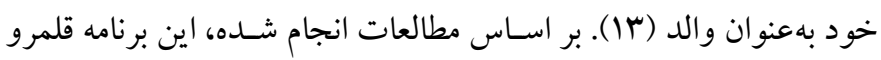

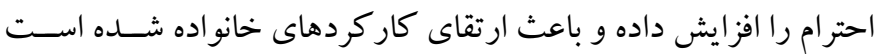

يُزوهش هايى درباره اثربخشـى آموزش والدگرى مثبت انجام شـــه

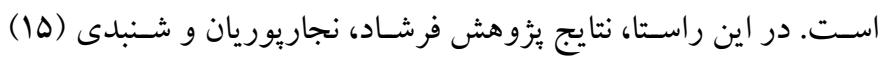

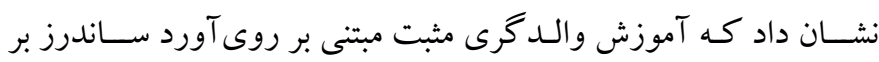
افزايش شـادزيستى و كاهش تعارض والد- فرزندى دانش آموزان، تأثير

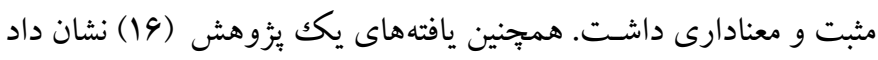

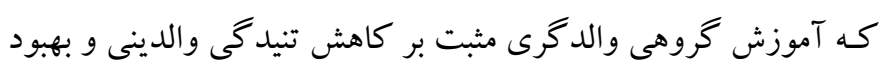

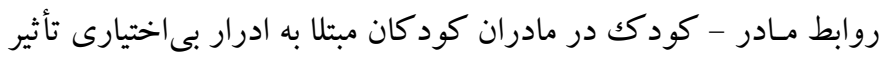

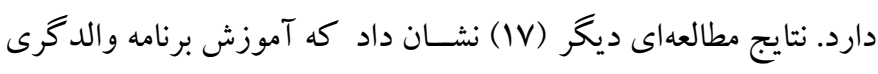

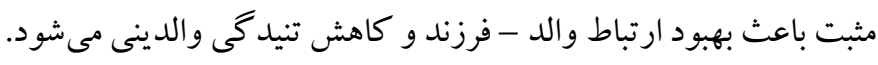

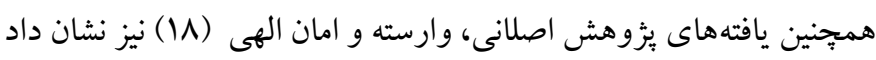

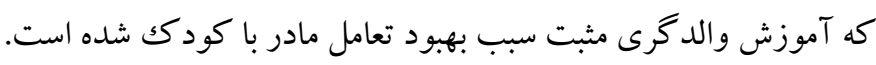

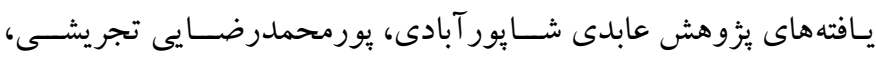

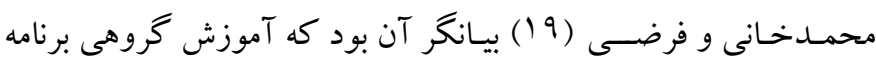

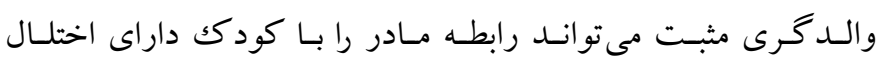

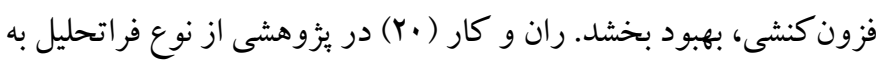

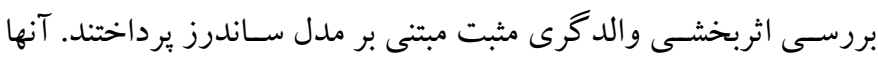

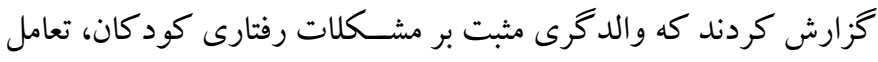

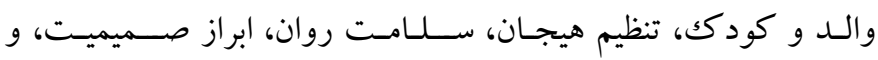

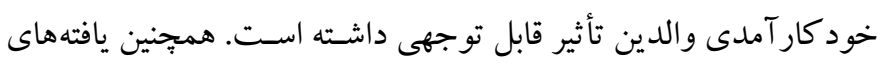

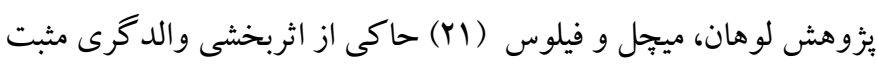


داشتن كود كان با مشكلات رفتارى معنادار بر اساس نمره ملاكك برسشنامه كانرز، زندگى كردن كودكك با دو والد و عدم جداييى والدين، نداشستن

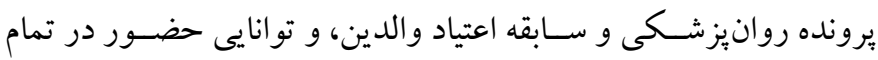

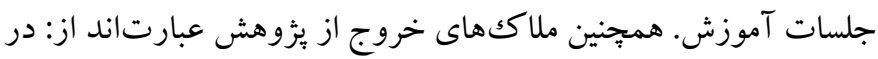

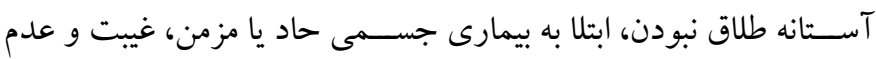
انجام تكاليف، اخلال در جريان آموزش، و شـركت در سـاير جلسـات

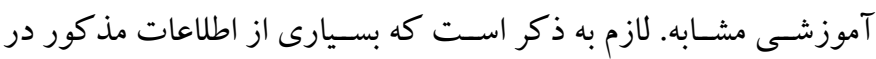

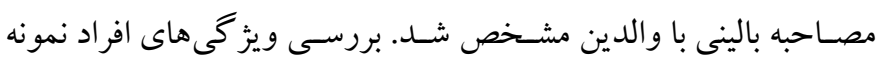

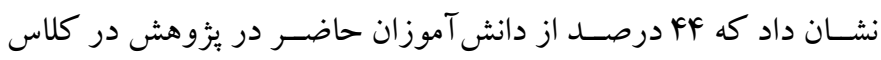

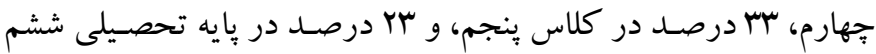

1. مقياس كانرز معلمان ': اين مقياس توســ كانرز در سـال .99 ابراى

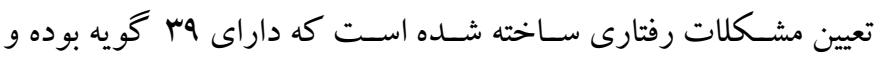

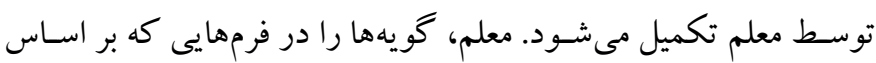

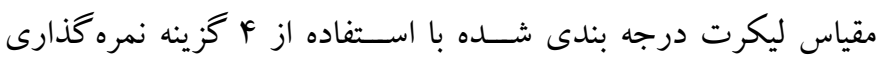

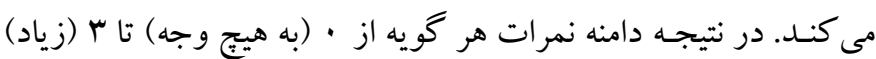

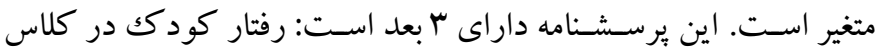

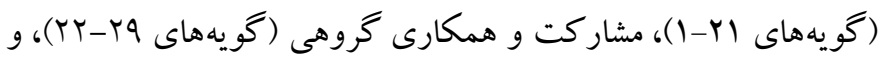

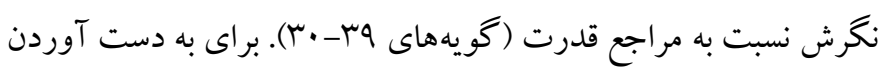

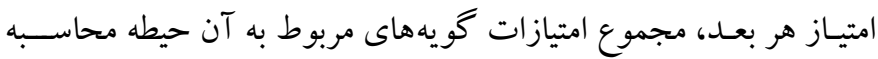
مى شـود و براى به دسـت آوردن امتياز كلى برسشنامه، مجموع امتيازات

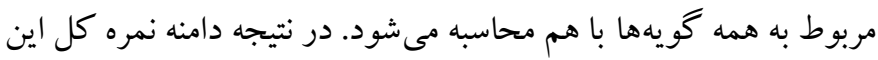

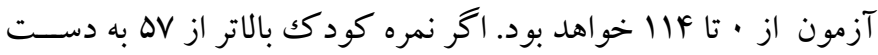

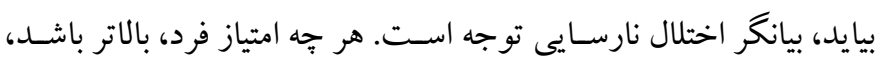
ميزان اختلال كودكك بيشتر خواهد بود و برعكس. اين برسشنامه داراى 9 خردهمقياس بوده كه بر اساس تحليل عوامل به

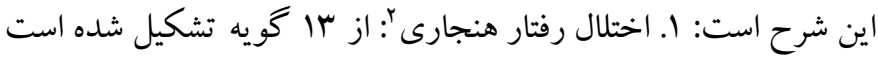

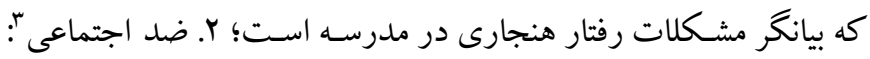

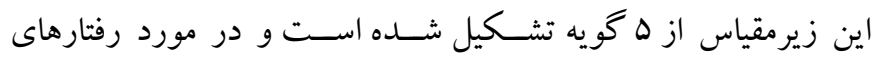

3. Anti social
بهترى نسـبت به مهارتهاى والدگرى خود و ويزگى هاى فرزند خود

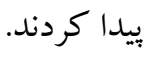

بـا توجه به اهميت رابطه والد - كود كك در تعاملات درونخانوادكى

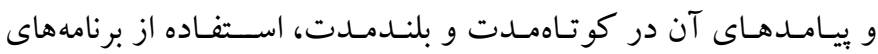
مداخلهاى و آموزشـىى، به مثابه بخش جدايىنايذير تعاملات بين فردى و

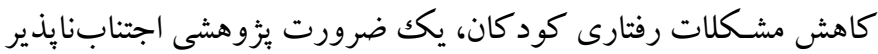
قلمداد مىشـود. بنابر اين از آنجايى كه مطالعات اخير به مدل برنامههاى

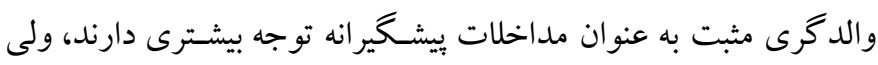

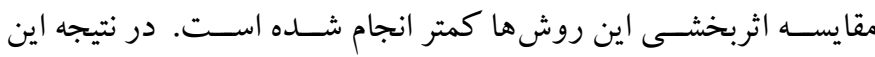

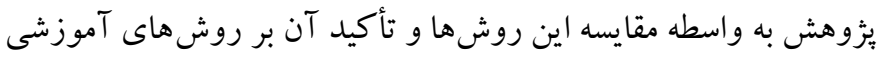

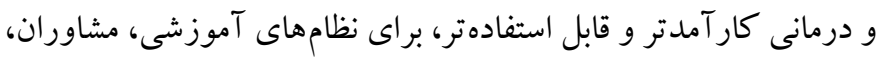
و خانو ادهها مفيد اسـت و موجب صـرفه جويى در هزينه و وقت مى شى دود. نتيجه اينكه يُزوهش حاضـر در صـدد ياسخ به اين سو ال انجام شده است

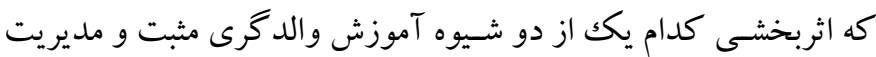
والدين بر رابطه والد - كودك، مؤثرتر است؟

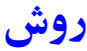

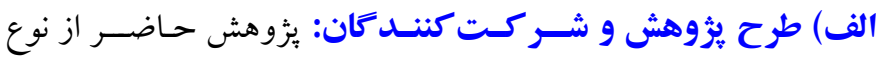

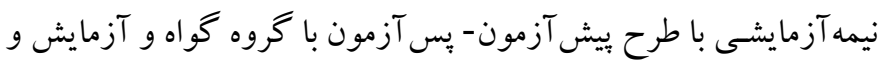

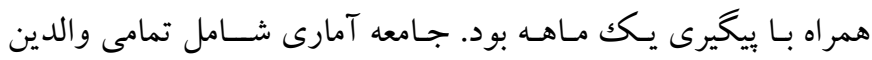
دانش آموزان دختر مبتلا به مشـكلات رفتارى مدارس ابتدايى منطقه يكك

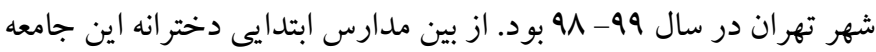
آمارى، ابتدا به صورت خوشهاى سه دبستان انتخاب شد و از هر دبستان،

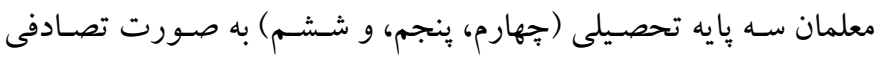

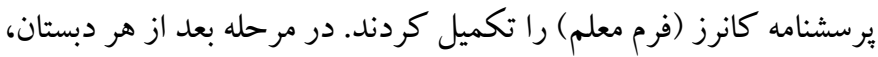
ها دانش آموز كه نمره بالايى در آزمون مشكلات رفتارى داشتند فهرست

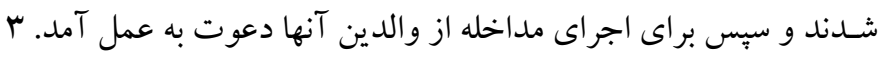

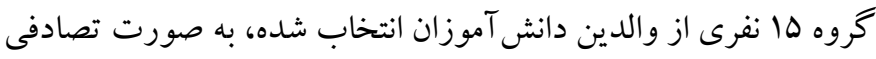

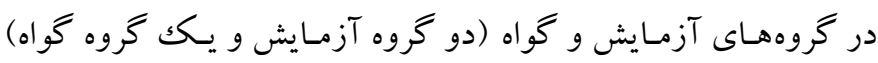
جايدهى شــند. ملاككهاى ورود آزمودنى ها در اين يُزوهش عبارت تراند

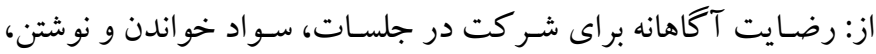

1. Conners' Teachers Rate Scale

2. Conduct disorder 
خود گزارش دهى اسـت و براى ســنش رابطه والد - كودك در تمام

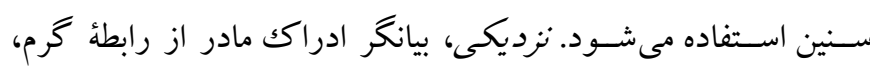
عاطفى، و ارتباط نزديكك با فرزند خويش اسـت. وابسـتكى، بيانكر

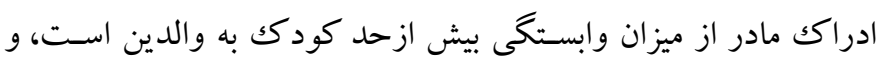

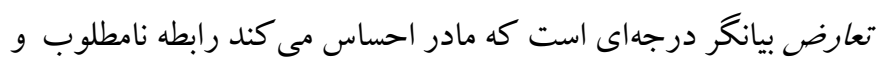

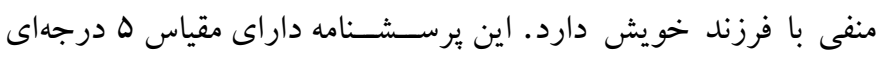
ليكرت است. شيوه نمره كذارى بر حسب باسخ هاى ا تا ها انجام مى شود. رابطه مثبـت كلى كـه همـان نمره كـل اســت از مجموع نمرات حوزه نزديكى و معكوس نمرات حوزه تعارض و وابسـتخى به دسـت مئس آيد.

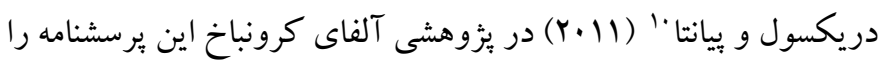

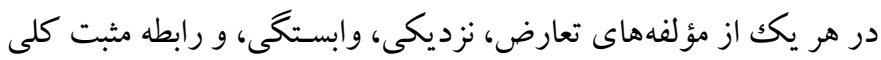

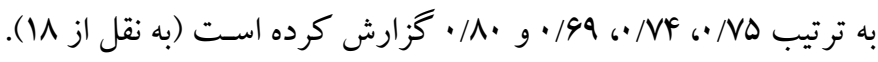
در بزوهش عاشورى و احمديان، روايى اين مقياس /N/ • و ضريب بايايى

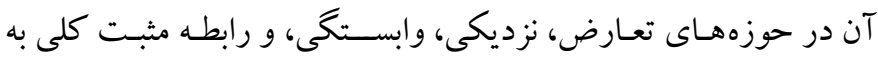

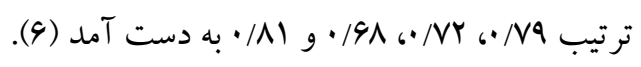

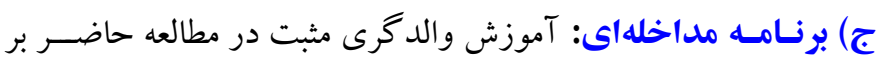

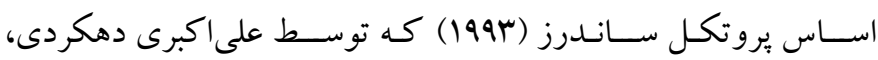

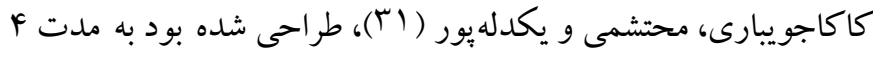
هفته و هر هفته Y جلسـه •9 دقيقهاى اجرا شـد. آموزش مديريت والدين

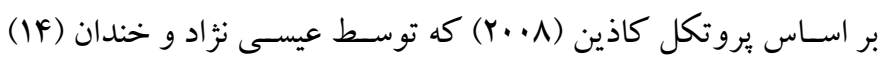

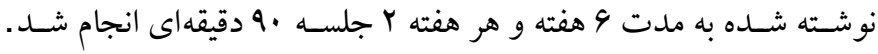

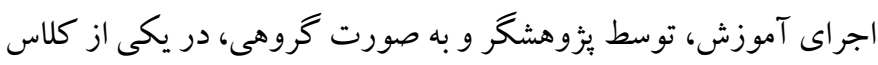
هاى مدرسه انجام شد.

\section{Closeness}

7. Dependency

8. Conflict

9. Positive general interaction

10. Discroll, \& Pianta
ضداجتماعى كودكك در مدرسه است؛ س. رويايردازى - مشكلات توجه ا:

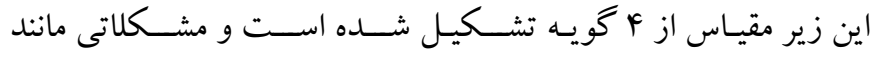
كوشـه گيرى و دورى از سـاير كودكان و در خواب و خيال بودن را شـامل مى شــود؛ F. اختلال نارسـايى توجه / فزون كنشـى بـ از IV كويه تشـكيل شـده اسـت كه V مورد از اين گويهها به زير مقياسهاى ديخر مانند مشـكلات رفتار هنجارى يا سـهلانكارى هيجانى هم تعلق دارند.؛ ه. اضـطراب - انفعال "اّ: اين زيرمقياس از و گويه تشكيل شـده اسـت و مشـكلاتى مانند كوشـه كيرى و ناخن جويدن را بررسسى مى كند؛ و 9. سـهل انخارى هيجانى ث: از ^ گويه تشكيل شـده است و مشكلاتى مانند كريه كردن، اخمو بودن، نااميدى، و عصبانيت را شامل مىشود. كانرز در سال 1999 اعتبار باز آزمايى فرم معلم اين مقياس را در طى بـ يكك ماه تا يكك سال از MY/ • تا YA/· و بايايى بين نمره كذارى معلمان را

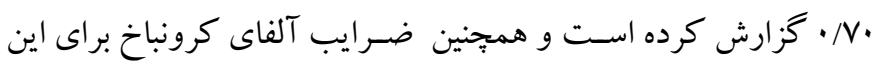

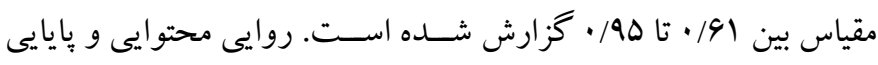
اين برسـشـنامه در ايران توسط شهيم و يوسـفى (IMNVV) به دسـت آمده اسـت. يايايى مقياس با روش بازآزمايى براى كل مقياس V9 / • و براى زيرمقيـاسهـا از 91/ • براى انفعالى بودن تا بر/· براى مشــكلات رفتار هنجارى متغير بود. ضـرايب آلفاى كرونباخ براى كل يرسـشـنامه معادل

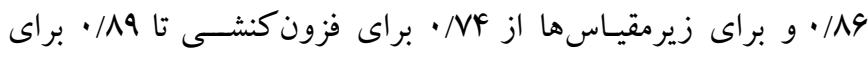
مشكلات توجه- رؤيايردازى، متغير بود ( •r). r- مقياس رابطه والد- فرزنده: اين مقياس توسـط بيانتا براى اولين بار در سـال 1994 سـاخته شـــ و شامل سب كويه است كه ادراكك والدين رادر مورد رابطه خود بـا كودكك مىســنجنـد. اين مقيـاس داراى حوزههـاى

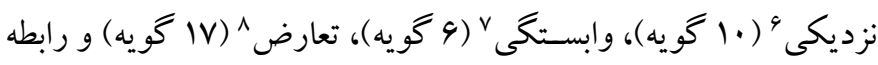
مثبت كلى ه (مجموع تمامى حوزهها) اسـت. اين مقياس يكك برسـشـنامه

1. day dream attention problems

2. ADHD (attention deficit hyperactivity disorder)

3. Anxious passive

4. Emotional overindulgent

5. Child-parent relationship scale 
جدول ا: جلسات آموزش والدكرى مثبت و آموزش مديريت والدين

\begin{tabular}{|c|c|c|c|c|}
\hline \multicolumn{2}{|l|}{ آموزش مديريت والدين } & \multicolumn{2}{|l|}{ آموزش والد } & \multirow{2}{*}{ جلسه } \\
\hline محتوا & اهداف & محتوا & اهداف & \\
\hline والدين به تعريف خاصى از رفتار كود كُ يرداخته و درمانكر تعريف & بر برى مشكلات & 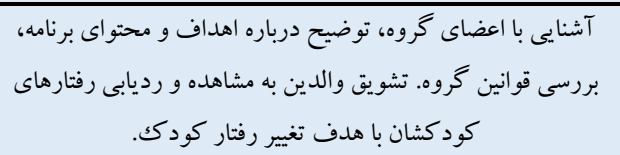 & معرفى برنامه & 1 \\
\hline 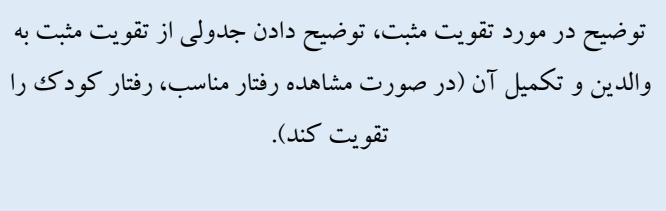 & تقويت مثبت تكنيك & 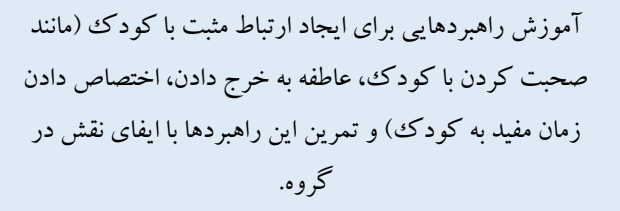 & كودك ارتقى نحول & r \\
\hline مرور تكاليف جلسه قبل، وقفه انداختن در تقويت (در صورت مشاهده. & 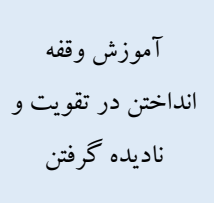 & 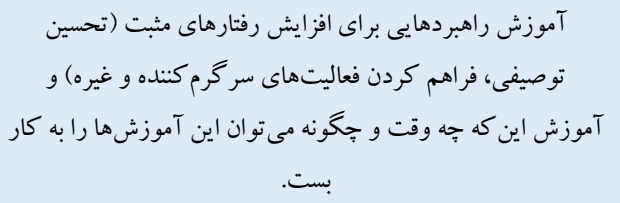 & كود ك r ارتقاى تحول & $r$ \\
\hline مرور تكاليف جلسه قبل، طرح توجه كردن و ناديده گرفتن & مرور موارد آموخته - م شده & 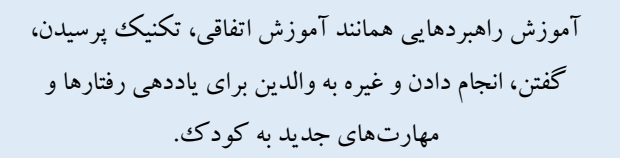 & كودك ك باى تحول & f \\
\hline توضيح شكل دهى رفتار خاص، تمرين به والدين، بررسى رفتار كودكى از طرف معلم و الدين & آموزش شكل دهى & 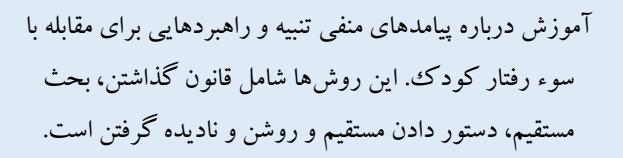 & ناكاريت رآمد إنتار & $\Delta$ \\
\hline 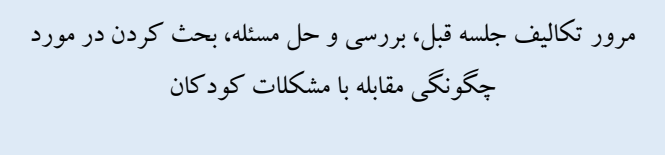 & آموزههاى والدين & 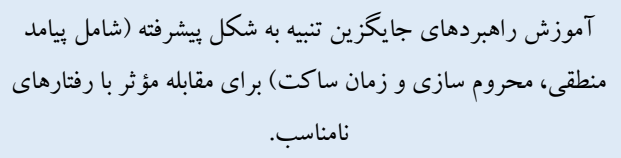 & 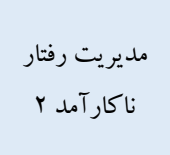 & 9 \\
\hline حضور كودكى و يدر و مادر، اصلاح رفتار هر يكك از آنها & اصلاح رفتار & 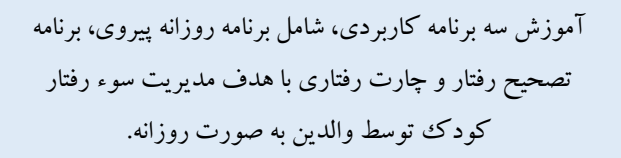 & 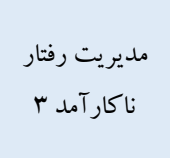 & $v$ \\
\hline 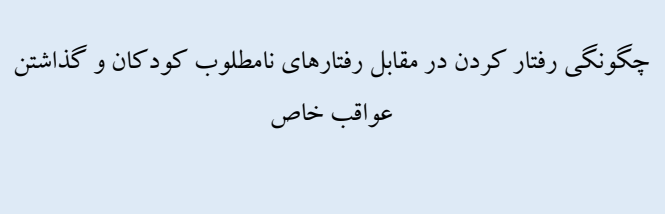 & رفتارهاى نامطلوب در مقابل & 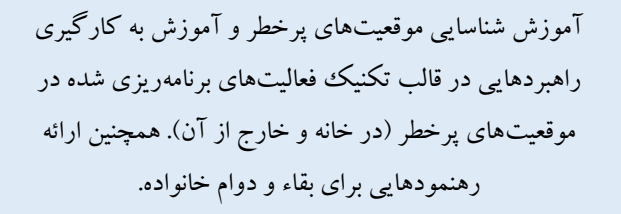 & 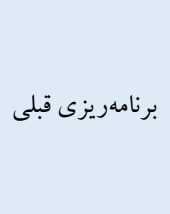 & $\wedge$ \\
\hline 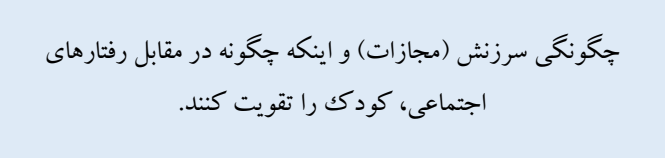 & هاى تنبيه و روش & & & 9 \\
\hline توافق كردن والدين در مورد جخگونخى رفتار كردن با كود كى خود. & والدماهنگ بين در رفتار & & & 11 . \\
\hline 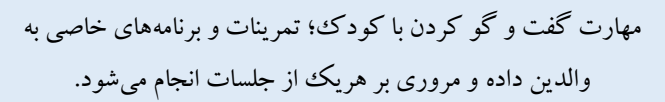 & آموزش كفتو گو با & & & ir \\
\hline
\end{tabular}

مورد نظر بر حسـب شـرايط ورود و خروج، انتخاب شدهاند و به صورت

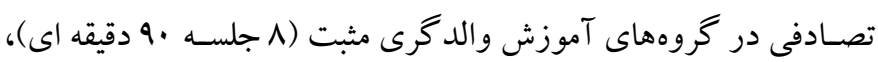
آموزش مديريت والدين (Yا جلسـه ·ه دقيقهاى)، و گروه گو اه (بدون
د) روش اجرا: بـه منظور اجراى ئزوهش حـاضـــر، ابتدا مجوزهاى للازم جهـت اجراى بزوهش از آموزش ويرورش كرفتـه شــــ و بـا مراجعـه به مدارس معرفى شده به شرحى كه در بخش روش ارائه شدف افراد نمونه 
براى تحليل دادههاى به دســت آمده در اين مطالعه از ميانكين، انحراف استاندارد، تحليل كوواريانس و آزمون تى استفاده شد.

نافتها

در جدول Y، آمارههاى توصسيفى متغير رابطه والد-كودكى، به تفكيك كروههـاى آزمايش و گو اه در مراحل بيش آزمون و يس آزمون گز ارش

شده است.
آموزش) جاىدهى شــدند. همجِنين جهت رعايت ملاحظات اخلاقى، در ابتداى انجام يثوهش، اهداف اين مطالعه براى والدين بيان شد و رضايت

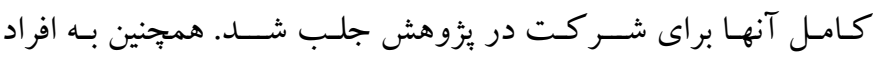
شـر كت كننده اطمينان داده شـــ كه اطلاعات حاصـل از اين بيزوهش به صـورت گروهى مورد تحليل قرار گرفته و براى توليد مسـتندات علمى

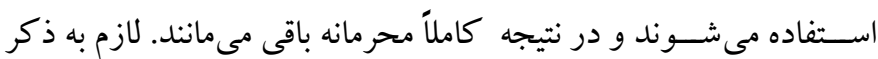
است كه گروه گ اهو در فهرست انتظار براى دريافت مداخله قرار كرفتند.

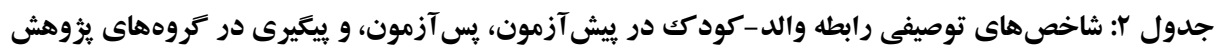

\begin{tabular}{|c|c|c|c|c|c|c|}
\hline $\mathbf{P}$ & شإيرو-ويلكز & انحراف استاندارد & ميانغين & وضعيت & كروه & خرده مقياس \\
\hline $.1 .9 \mathrm{~V}$ &.$/ 101$ & $r / f$. & $19 / 2$ & يِش آزمون & & \multirow{3}{*}{ عامل نزديكى } \\
\hline$\cdot / \cdot \Delta V$ & $\cdot / 109$ & $1 / F Y$ & $11 / 4$. & يس آزمون & & \\
\hline$\cdot \cdot v F$ & .11 .9 & r/rr & $1 r / r$. & ييخيرى & & \\
\hline$\cdot / \cdot v a$ & ( & 1/V9 & $\mid N / \Gamma$. & يِيش آزمون & & \multirow[b]{2}{*}{ عامل وابستگى } \\
\hline$\cdot / \cdot V r$ & $\cdot / 1 \cdot r$ & $r / 9$. & $19 / 1$. & بِ آزمون & & \\
\hline$\cdot / \cdot$. & .1 .91 & $r / f$. & $1 N / 9$. & ييخيرى & آزمايش 1 & \multirow[b]{3}{*}{ عامل تعارض } \\
\hline$\cdot / \cdot V \Delta$ & $\begin{array}{l}.11 \cdot 1 \\
.1 .90\end{array}$ & $9 / \pi 1$ & FN/I. & يِش آزمون & و الدگرى مثبت & \\
\hline $\begin{array}{l}\cdot / \cdot 11 \\
\cdot / \cdot v 1\end{array}$ & $\begin{array}{l}. / .90 \\
. / 114\end{array}$ & $\mathrm{~V} / \mathrm{VA}$ & $\begin{array}{l}\Delta r / . \cdot \\
\Delta q / \cdot .\end{array}$ & 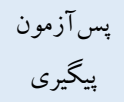 & & \\
\hline$\cdot / \cdot v 1$ & $\cdot / 1 \cdot \Delta$ & $9 / 11$ & $9 \vee / r$. & ي يش آزمون & & \multirow{3}{*}{ نمره مثبت كلى } \\
\hline$\cdot / \Lambda$. & $\cdot / \cdot \vee \wedge$ & $Q / \Gamma \Delta$ & $V F / r$. & يس آزمون & & \\
\hline.$/ \cdot 1 \wedge \mathrm{V}$ & $\cdot / \cdot \wedge r$ & $11 / M$ & VQ/9. & يِيرى & & \\
\hline$\cdot / \cdot V F$ & $\cdot / 1 \cdot 1$ & $r / F r$ & $I V / 4$. & يِيش آزمون & & \multirow{3}{*}{ عامل نزديكى } \\
\hline.$/ 11 r$ &.$/ .9 V$ & $1 / 94$ & $11 / \mathrm{v}$ & يس آزمون & & \\
\hline.$/ 110$ & .1 .91 & $r / T 4$ & $1 r / \Delta$ & ييخيرى & & \\
\hline.$/ 11 r$ & $M . F$ & $4 / .9$ & $1 \pi / 1$. & يِيش آزمون & & \multirow{3}{*}{ عامل وابستخى } \\
\hline.$/ 111$ &.$/ .9 Y$ & $r / r q$ & $r M / r$. & يֶ آزمون & & \\
\hline.$/ 1 Y 4$ & $\cdot / \cdot 19$ & $r / .9$ & 19/9. & ي ي & آزمايش r & \\
\hline$\cdot / r \cdot$. & $.1 .9 \mathrm{~V}$ & $Q / T V$ & Fr/G. & يِيش آزمون & (مديريت والدين) & \multirow{3}{*}{ عامل تعارض } \\
\hline$\cdot / r \cdot$. & $\cdot / \cdot \mathrm{VA}$ & r/Ar & $9 V / 4$. & يس آزمون & & \\
\hline.$/ 191$ & $\cdot / \cdot 11$ & $N / \Delta 9$ & $91 / 0$. & ييخيرى & & \\
\hline$\cdot / r \cdot$ & $\cdot / \cdot \sqrt{ } q$ & $1 \cdot / 4 r$ & $1 \cdot \Delta / V$ & يِيش آزمون & & \multirow{3}{*}{ تمره مثبت كلى } \\
\hline$\cdot / l \Delta F$ &.$/ .91$ & $\Delta / \wedge q$ & $9 \mathrm{~V} / 1$. & يس آزمون & & \\
\hline . /195 & $\cdot / \cdot \wedge \vee$ & $11 / \Delta \Lambda$ & $V G / f$. & ييخيرى & & \\
\hline$\cdot / r \cdot \cdot$ & $\cdot / \cdot \mu \wedge$ & $r / \Delta \Lambda$ & $10 / A$ & يِش آزمون & & \multirow{2}{*}{ عامل نزديكى } \\
\hline$\cdot / r \cdot$. & $.1 .9 \mathrm{~V}$ & $r / v V$ & $10 / 4$ & بِ آزمون & & \\
\hline$\cdot / r \cdot$ &.$/ .4 q$ & r/M & $\mid r / 1$. & يِيش آزمون & كواه & \multirow{2}{*}{ عامل وابستخى } \\
\hline$\cdot / 1 \wedge 9$ &.$/ . \Delta 9$ & $r / 19$ & $\mid r / 4$. & بِ آزمون & & \\
\hline$\cdot / 1 \cdot 1$ &.$/ .91$ & $V / r I$ & Fr/9. & ييش آزمون & & عامل تعارض \\
\hline
\end{tabular}




\begin{tabular}{|c|c|c|c|c|c|}
\hline .11 .9 &.$/ .9 \mathrm{~V}$ & V/ar & $\mathrm{kr} / \mathrm{V}$. & يִ آزمون & \\
\hline.$/ 11 r$ &.$/ .94$ & $1 \cdot / A F$ & $1.4 / 1$. & بيش آزمون & \multirow{2}{*}{ نمره مثبت كلى } \\
\hline $.11 \cdot 0$ &.$/ \cdot 1 \cdot r$ & $\mid r / \cdot \cdot$ & $1 . r / 0$. & يִ آزمون & \\
\hline
\end{tabular}

كوواريـانس برقرار اســت (ه •/p>). مفروضــه همكنى شـيـب خط ركرسيون با اثر تعامل بيش آزمون و متغير وابسته رابطه والد-كودكك در كروههـاى ئزوهش مورد بررسـى قرار كرفت كه نتيجه به دســت آمده معنادار نيسـت (ه • p p)؛ در نتيجه دادهها از مفروضـهـ همخنى شـيب ركرسـيون يشـيبانى مى كنند. نتايج آزمون خى دو بارتلت براى بررسى كرويت يا معنادارى رابطه بين مؤلفههاى رابطه والد-كودكك نشان داد كه

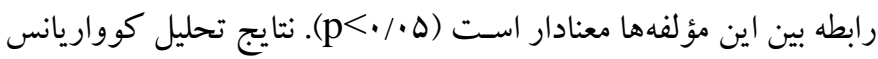
نشـان داد مقدار آماره لامبدا در سطح | • • معنادار است ( $191 /$ •= للامبدا

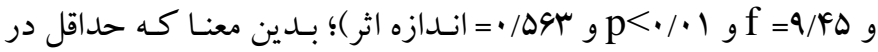
يكى از خرده مقيـاسهـاى متغير (رابطهه والـد-كودكى) در بين كروههـا تفـاوت وجود دارد؛ بنـابر اين بـه بررسـى نتـايج تحليل كوواريانس تكك متغيرى و آزمون تعقيبى بنفرونى برداخته شد. در جـدول ل، نتايج تحليل كوواريانس تككمتغيرى براى بررسـى تفـاوت گروههـاى آزمـايش و گواه در يِش آزمون با بس آزمون متغير رابطه والد-كود كى خزارش شده است.
جـدول Y نشــان مىدهـد كه ميانكين نمره مثبت كلى در پيس آزمون كروه آزمايشـى تحت آموزش والدكرى مثبت، كاهش يافته اسـت ولى نمره عامل هاى وابسـتكى و تعارض در يس آزمون افزايش داشـته اسـت. همجينين ميـانگين نمره مثبـت كلى و عـامل نزديكى در بس آزمون كروه آزمايشسى تحت آموزش مديريت والدين، كاهش يافته اسـت؛ ولى نمره عامل هاى وابســــى و تعارض در يس آزمون، افزايش داشــته اســت و ميانگين عاملهاى مقياس رابطه والد-كودكك در يس آزمون گرووه گو اه، تغيير جندانى نداشته است.

جهت بررسى مقايسـه اثربخشى آموزش والدكرى مثبت و آموزش مـديريـت والـدين بر رابطه والـد-كودك، از تحليـل كوواريـانس جند متغيرى اسـتفاده شـــ. ابتدا مفروضـههاى تحليل كوواريانس مورد بررسى قرار گرفت. نتايج آزمون شـاييرو - ويلكز نشان داد توزيع باقيماندهها در متغيرهاى وابسـته نرمال اسـت (ه •/P> P). نتايج آزمون لوين نشـان داد مفروضسه همخنى واريانس ها در متغيرهاى يزوهش، برقرار است (ه • ••> p pتـايج آزمون ام بـاكس نيز نشــان داد مفروضــهـ همخنى مـاتريس

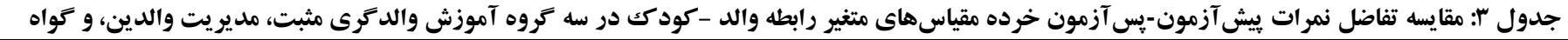

\begin{tabular}{|c|c|c|c|c|c|c|c|}
\hline اندازه اثر & سطح معنى دارى & Tاره Fا Fا & ميانكين مجذورها & درجه آزادى & مجموع مجذورات & منابع تغييرات & متغير \\
\hline$\cdot / Y \Delta V$ & $\cdot / \cdots$ & N/r & $r q / 1 r$ & 1 & $r q / 1 r$ & يِش آزمون & \\
\hline$\cdot / 0$. &.$/ .1$ & $\mid r / \cdot 1$ & $\Delta q / q q$ & r & $11 Y / 9 \Lambda$ & عضويت گروهى & عامل نزديكى \\
\hline - & - & - & $\mathrm{F} / \mathrm{V}$. & mq & $11 r / 9 V$ & خطا & \\
\hline.$/ \mu_{\Lambda}$ & $\cdot / \mu F$. &.$/ 94 A$ & $V / M F$ & 1 & V/MFA & يشي آزمون & \\
\hline.$/ 9 K F$ & $\% \cdot 1$ & 19/9r & $\mid \Delta F / \Gamma \Lambda$ & r & $r \cdot \Lambda / V V$ & عضويت گرروهى & عامل وابستخى \\
\hline - & - & - & V/VFV & rq & IND/QYY & خطا & \\
\hline.$/ 1 V^{2}$ & (1/ & $0 / \cdot 1$ & $\mid \Lambda V / r \cdot 1$ & 1 & $\mid \Lambda V / \mu \cdot 1$ & يُيش آزمون & \\
\hline$\cdot / v \Delta V$ &.$/ \cdot 1$ & $r V / r V$ & IrQ৭/QF & r & rVar/Aq & عضويت گروهى & عامل تعارض \\
\hline- & - & - & $\mathrm{rV} / \mathrm{TV}$ & rq & $\wedge 9 \vee / .$. & خطا & \\
\hline
\end{tabular}

معنادار اسـت. ميزان اندازه اثر نشـان مىدهد •له درصسد از تغييرات عامل نزديكى، بو درصـد از تغييرات عامل وابستخًى، و VD درصد از تغييرات
با توجه به نتايج جدول آ نمرات يس آزمون در مؤلفه هاى رابطه والد - كودكك (1 (P P) در بين كروههـاى آزمايش و كواه، داراى تفاوت 
عامل تعارض، ناشسى از عضويت گروهى است. براى اينكه بدانيم تفاوت

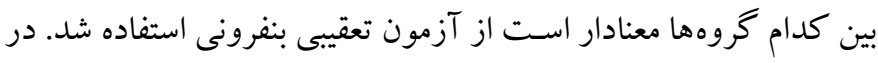

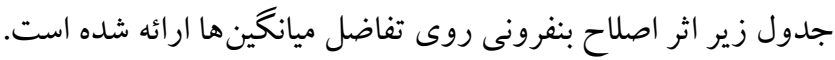

جدول ع: تفاوت ميانعين ها و دامنه اطمينان تفاوتها به تفكيك كروههاى ثزوهش

\begin{tabular}{|c|c|c|c|c|c|c|c|}
\hline دامنه بالا & دامنه هايين & معنادارى & انحر اف استاذدارد & تفاوت ميانكين ها (J-I) & (J) & (I) & مؤلفه \\
\hline r/QY & & & & & & & \\
\hline $1 / 41$ & $-r / \Delta V$ & $1 / \cdot \cdot$ & $1 / 49$ & - & آموزش مديريت والدين & آموزش والدكرى مثبت & \\
\hline \multirow[t]{2}{*}{$-1 / 9 r$} & $\Lambda / \Lambda$ &.$/ \mu$ & $\mid / \mu 1$ & $-F / v q$ & آموزش والدگرى مثبت & & عامل نزديكى \\
\hline & $-V / \cdot r$ &.$\cdots 1$ &.$/ 99$. & $-F / F V$ & كواه & زش مديريت والدين & \\
\hline $1 / \%$. & $-V / I F$ & . TrA & $1 / 94$ & $-Y / 99$ & آموزش مديريت والدين & آموزش والدگرى مثبت & \\
\hline$-9 / \Gamma \wedge$ & $-\cdot / v \cdot \cdot$ &.$/ .19$ & 1/91 & $-\Delta / \cdot F$ & آموزش والدگرى مثبت & كواه & عامل وابستىى \\
\hline $11 / Y \wedge$ & $F / V F$ &.$/ \cdot 1$ & $I / Y V$ & $-\Lambda / \cdot 1$ & كواه & امورس مديريـ وادين & \\
\hline I/YY & $-1 V / \cdot 9$ & .11 .4 & $r / \Delta 9$ & $-V / a r$ & آموزش مديرت والدين & آموزش والد گرى مثبت & \\
\hline$-r \Delta / 9 \varphi$ & $-9 / 09$ &.. .1 & $r / v$. & 1911. & آموزش والدكرى مثبت & گو اه آموزش مديريت والدين & عامل تعارض \\
\hline $19 / 19$ & MI/Yr & & $r / v q$ & $r F / . F$ & كواه & & \\
\hline
\end{tabular}

براى اينكه بدانيم آموزش والدكرى مثبت و مديريت والدين بر بهبود رابطه والـد-كودكك در مرحلـه بيخيخى مؤثر بوده اســت از آزمون تى همبسته استفاده شد. نتايج آزمون لوين جهت بررسى همخنى واريانس ها نشـان داد همخنى واريانسها در متغيرهاى يثوهش، برقرار است (ه •/.• p pe بنابراين نتايج آزمون t با فرض برابرى واريانسها در جدول ه، ارائه

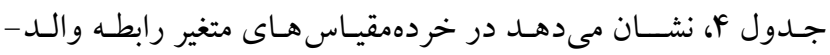
كودك، تفاوت بين گروههاى آزمايشسى معنادار نيســ؛ ولى تفاوت بين كروههاى آزمايشى با گروه گواه، در تمامى خرده مقياس ها معنادار است. بنابراين مى توان كفت ضــمن اثربخشـى هر دو روش آموزشـى، هر دو اثربخشى يكسانى بر رابطه والد-كودكك داشتهاند.

شده است.

جدول 0: نتايج آزمون t براى مقايسه متغير ها در كروههاى تحت آموزش

\begin{tabular}{|c|c|c|c|c|c|c|}
\hline سطح معنادارى & درجه آزادى & آماره تى & انحر اف استاندارد & تفاوت ميانكين بين دو مرحله هِ آزمون- يِيكيرى & تعداد & كروه \\
\hline .1 .94 & if & $-r / 1 r$ & $\mathrm{~V} / \mathrm{M}$ & $\Delta / r$. & 10 & والدگرى مثبت \\
\hline$\cdot / \cdot r \mid$ & If & $-Y / V q$ & $1 \cdot / \Delta r$ & $9 / \%$. & 10 & 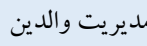 \\
\hline
\end{tabular}

مثبت، رابطه والد-كودكك بهبود داشـته اسـت؛ بنابراين مىتوان كفت كه بعـد از يـك مـاه، تأثيرات آموزش والدكرى مثبت بر بهبود رابطه والد كودكك، ادامه داشـته اسـت. در كروه تحت آموزش مديريت والدينى، تفاوت بين رابطه والد-كودكك، در سـطح ه • • معنادار است. با توجه به جداول آمار توصيفى و ميانكين ها، مى توان گفت ميانكين در متغير رابطه
همانطور كه در جدول ه ملاحظه مىشـود در گروهه تحت آموزش والـدكرى مثبت، تفاوت بين رابطه والد-كودك، در مرحله يس آزمونييخيرى معنادار نيســت. با توجه به جداول آمار توصـيفى و ميانخينها، مى توان كفـت تغييرات حـاصـل شــده در مرحلـه يس آزمون در مرحله ييكيرى نيز ثابـت مـانده اســـ؛ بدين معنا كه در اثر آموزش والدكرى 
مىشود آن دسته از ويزگى هاى مادران كه بر توانايى والدگرى آنها مؤثر

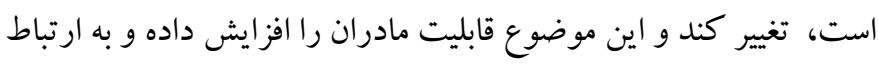

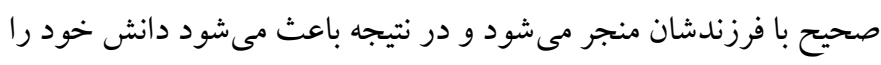

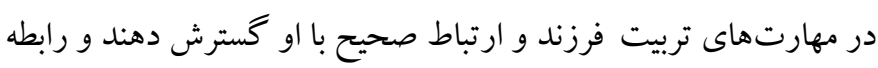

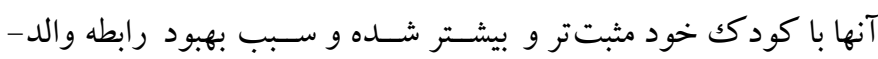

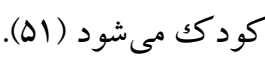

همجينين نتايج اين مطالعه نشان داد كه آموزش مديريت والدين سبب

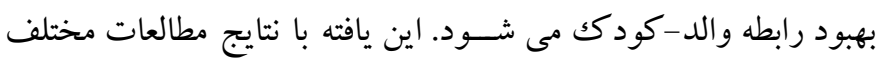
(9Y-YV)

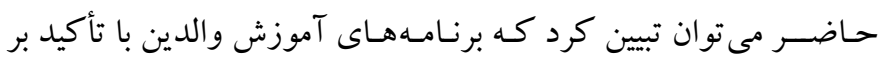

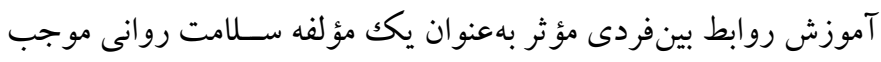

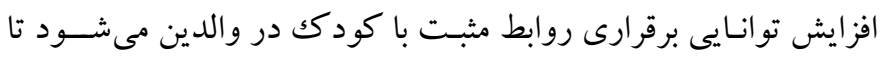

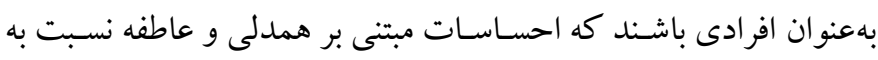

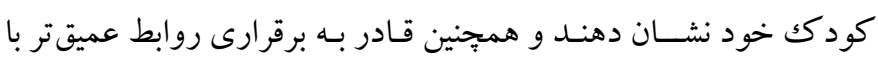

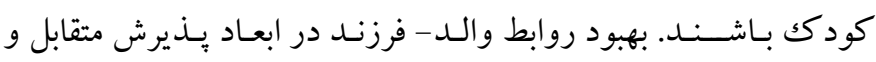
مديريت تعارض هاى بين والدين و فرزندان انجام مى شود. در اين برنامهها

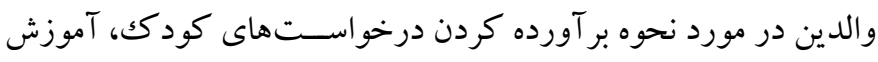

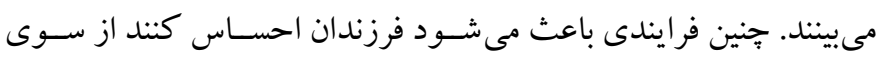

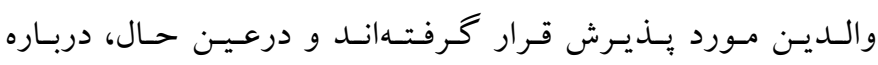

درخواستهايشان نيز با تعارض مواجه نشوند (A).

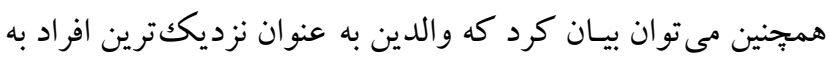

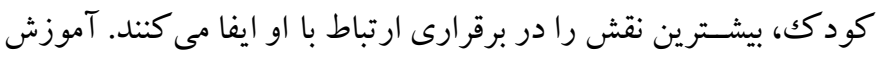

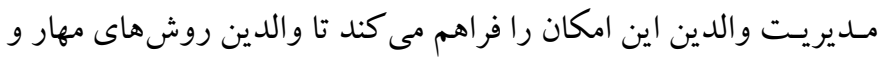

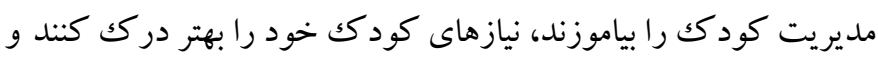

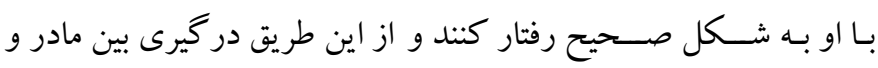
كودك، كـاهش مى يابد كه اين موضـون خود باعث افز ايش روابط و

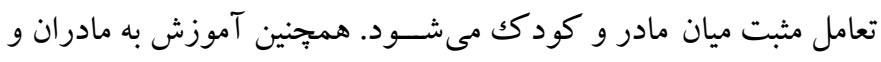

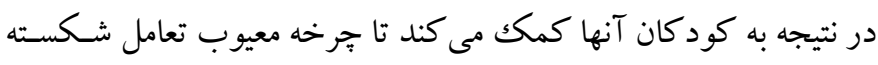

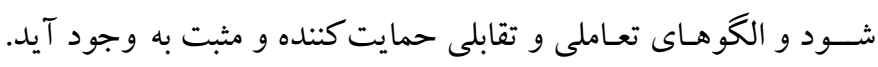

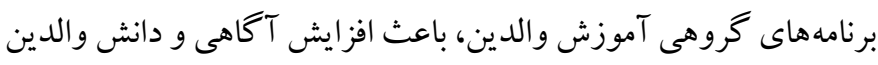

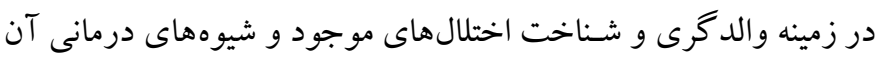

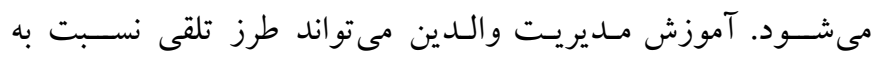

والـد-كود كك در مرحله بيخيرى نســــت به مرحله بِ آزمون، افزايش

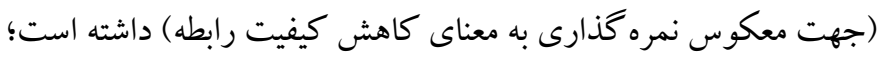

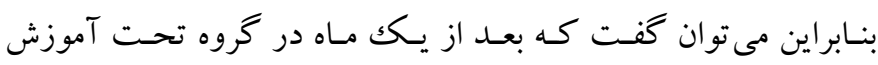

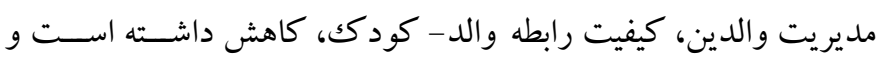
آموزش اثر خود را از دست داده است.

\section{بحث و نتيجه كيرى}

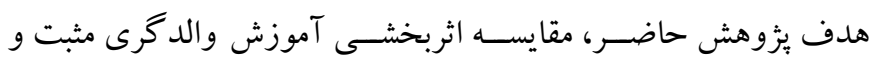

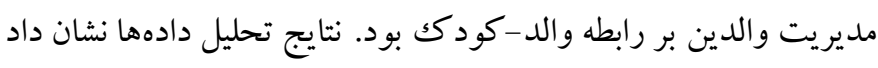

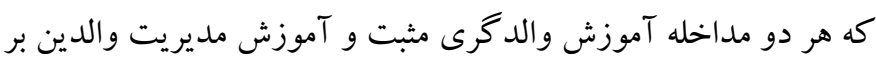

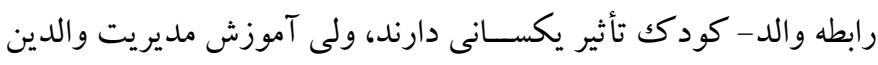

در مرحله ييخيرى كاهش رابطه والد-كود كك را به دنبال داشته است.

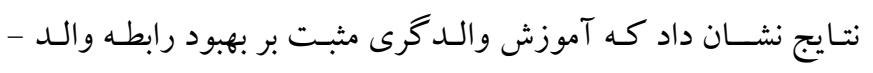

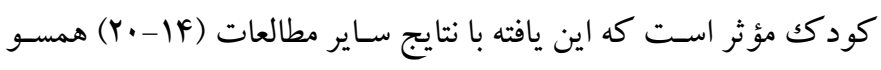

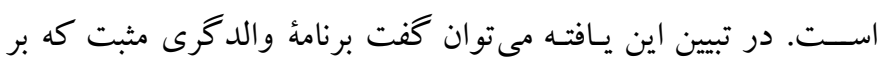

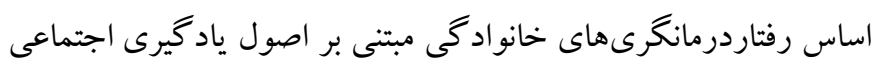

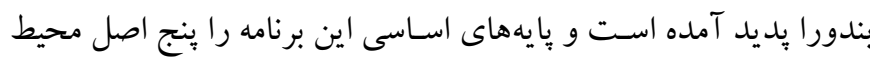

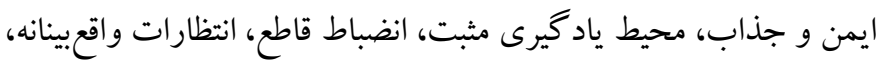

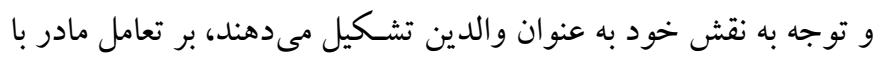

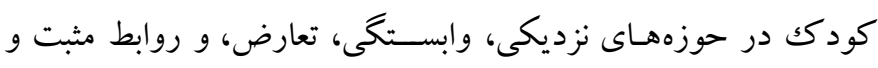

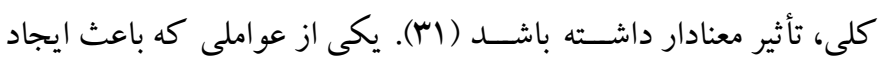

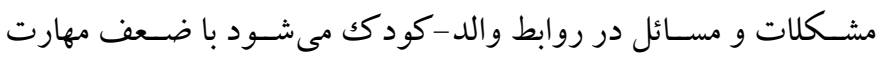

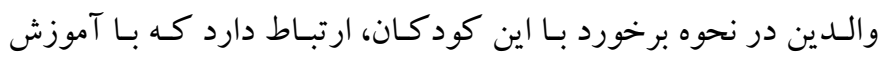

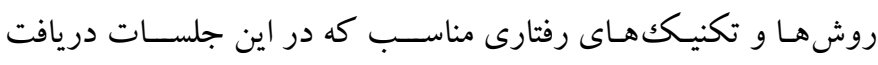

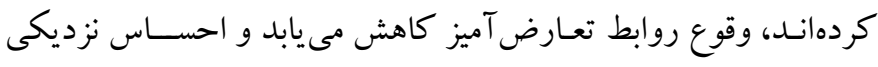

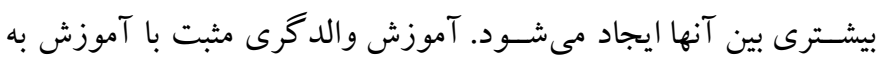

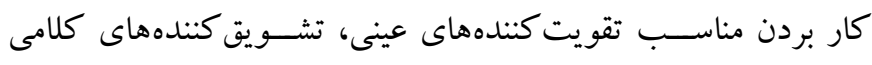

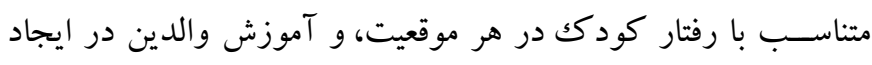

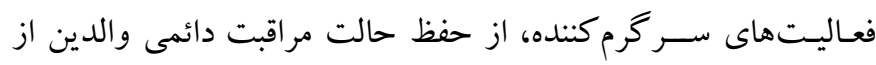

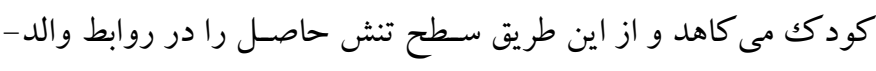

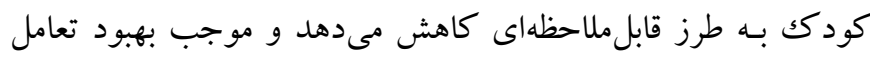

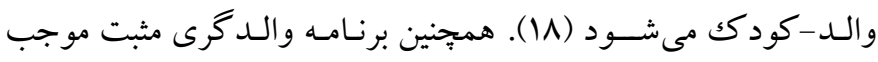


يِيَيرى شــده باشـد. هر دو گروه را آموزش دهند كان يكسـانى هدايت

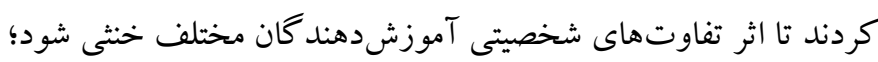

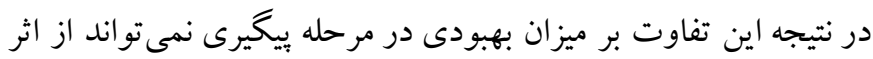

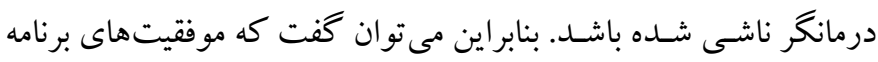

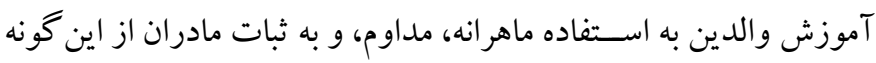

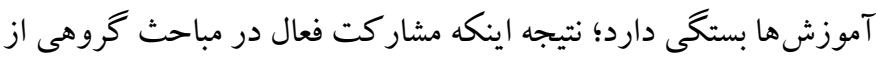

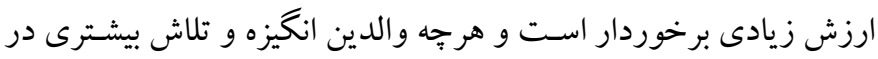

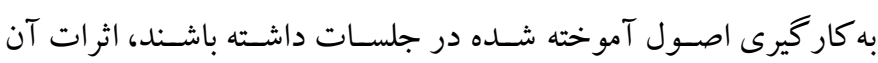

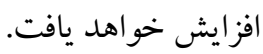

توجه به شناخت روش هاى مداخلهاى كار آمدتر و با اندازه اثر بيشتر،

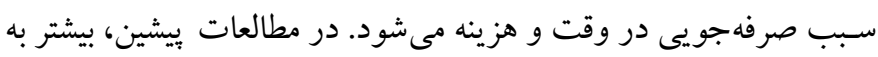

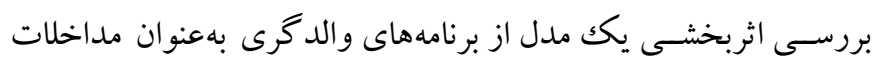

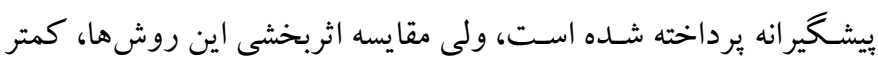

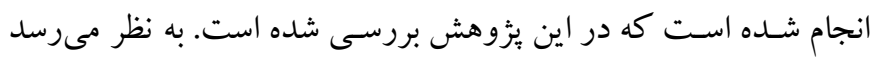
هر دو مداخله مى توانند به عنوان برنامه مداخله جامع براى بهبود برد رابطه

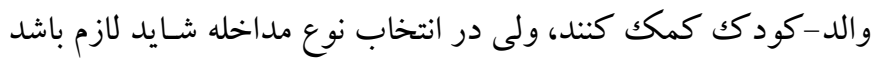
بررسى بيشترى روى مشكلات ارتباطى والد و كودكك انجام شود و در

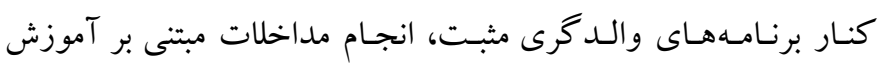

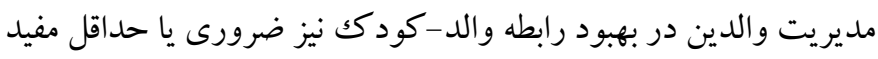
به نظر مىرسد. از محـدوديـتهـاى اين بزروهش مى توان به محدوديت در انتخاب و

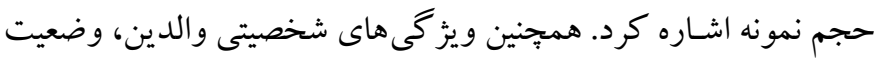

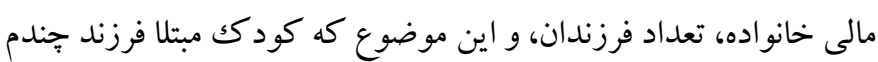

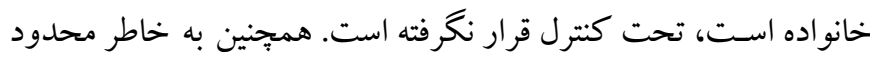
بودن شر كت كنند گان به پايه سوم، جهارم و ينجم دبستان، از تعميم نتايج

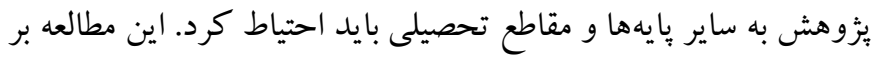

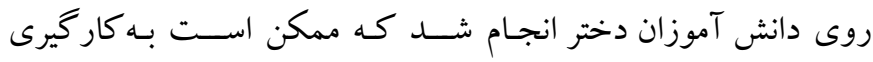

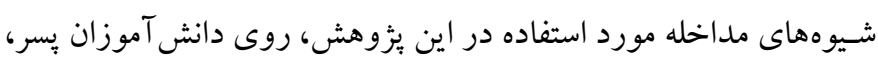

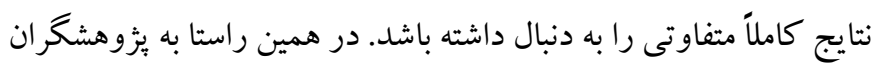

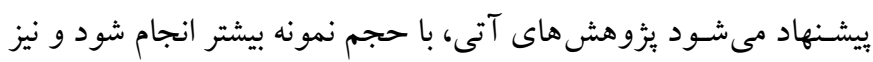

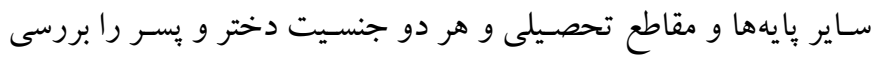

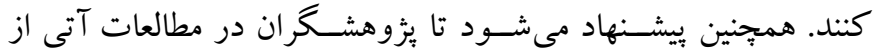

والددرى و نوع نخاه مادران به ماهيت روابط والد -كودكى را با واقعيت منطبق سـازد. بدين صسورت كه با يذيرش برخى كشاكشهاى

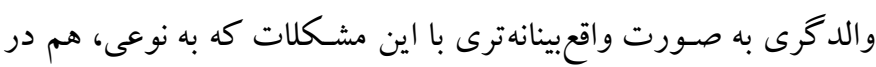
زندگى گذشته و هم در روابط كنونى خود با فرزندان تجربه مى كنند،

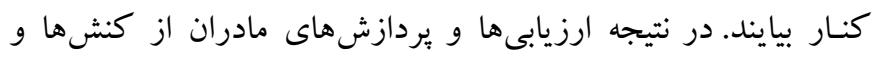

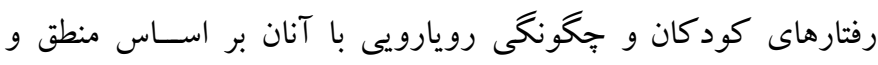

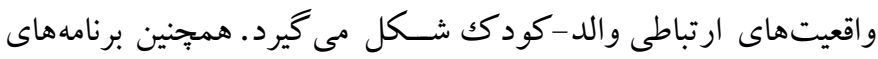

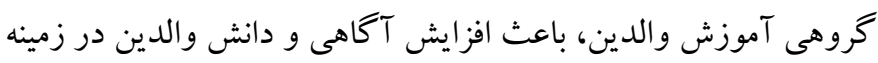

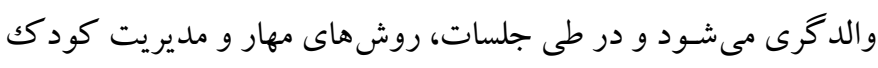

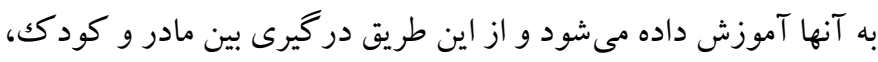

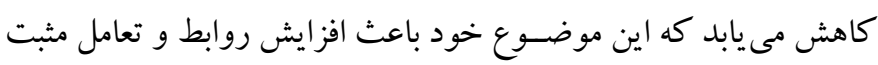
ميان مادر و كودكك مىشود در مقايسـه اثربخشى اين دو روش، نتايج اين مطالعه نشان داد كه هر

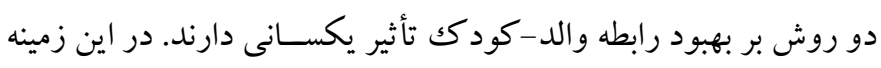

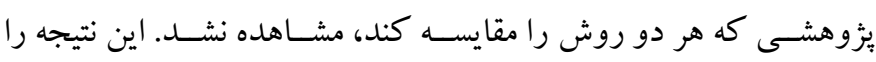

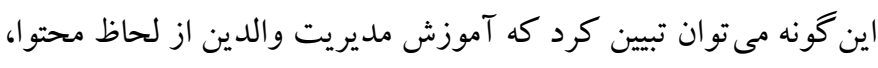

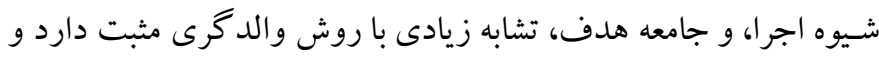

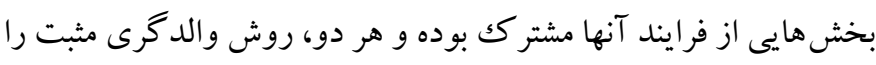

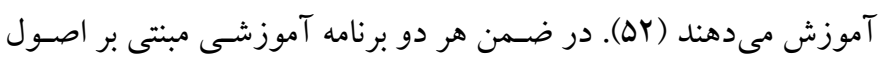

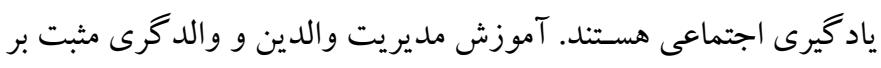

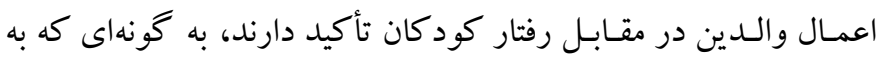
جاى تنبيه و مجازات سـخت، از محروميت و سـكوت؛ و در مقابل رفتار

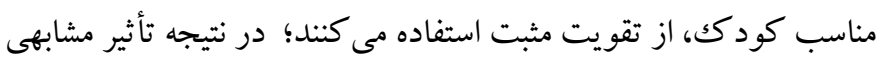
بر بهبود رابطه والد-كود كك دارند.

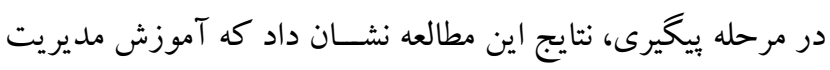

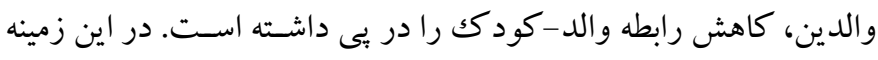

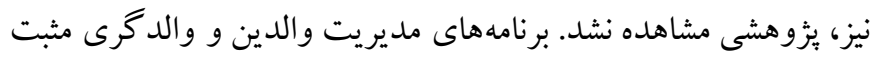

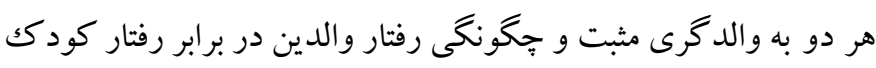

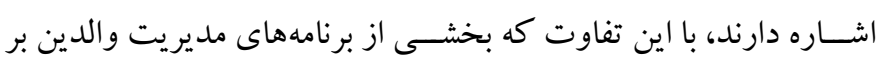

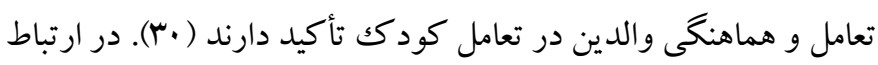

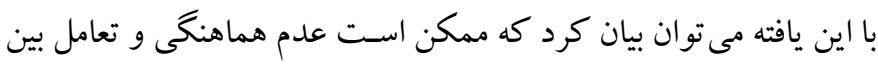

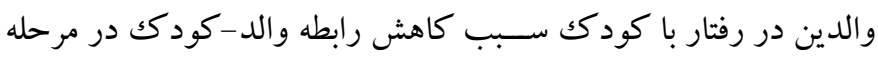


ملاحظات اخلاقى

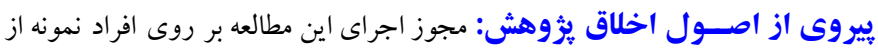

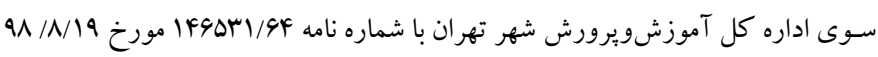

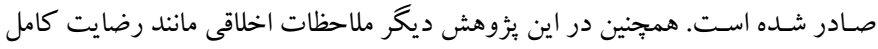
افراد نمونه و رعايت اصل رازدارى و محرمانه ماندن اطلاعات رعايت شده است. حامى مالى: اين مطالعه بدون حامى مالى و در قالب رساله دكترا انجام شده است.

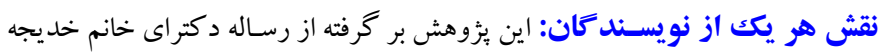

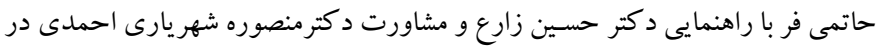

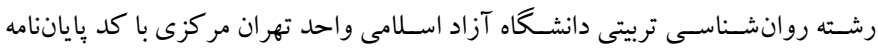

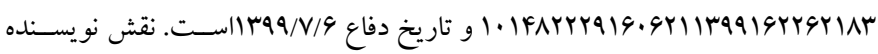

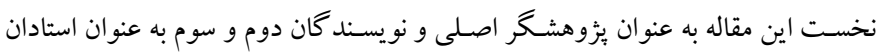
راهنما و مشاور اين بروزمه، نقش داشتند.

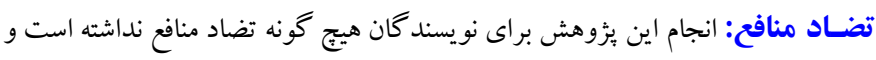

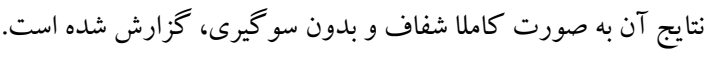

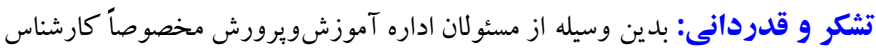

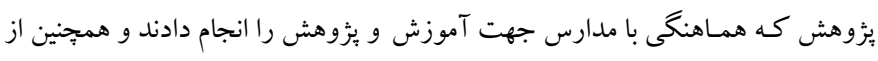

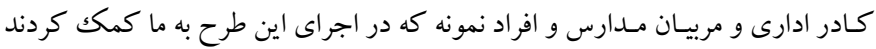
تشكر و قدردانى مى مودد.
طرحهاى تكك آزمودنى نيز براى تعيين اثربخشـى مداخله هاى مبتنى بر

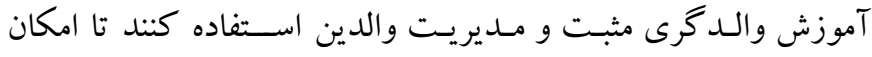

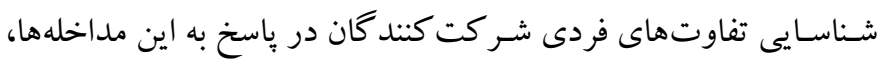

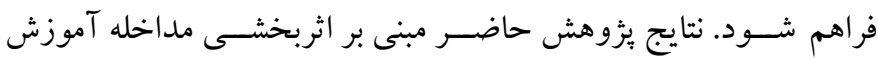

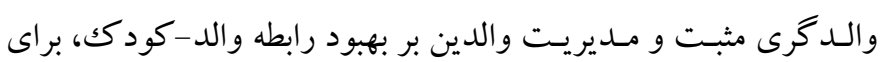

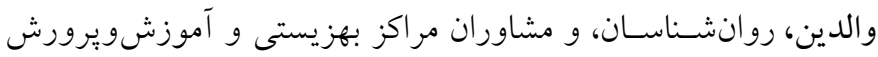

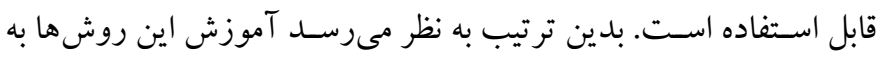

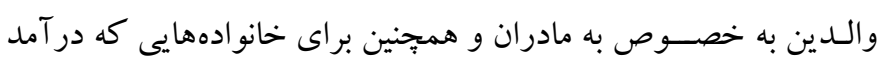

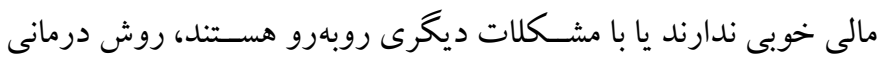
بسـيار نتيجهبخش باشــــ و با توجه به وســايل و هزينه بسـيار كمى كه

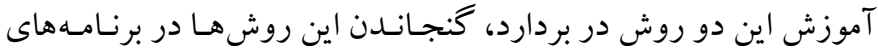
آموزشى دولتى، بيشنهاد مىشود. 


\section{References}

1. Rostad WL, Whitaker DJ. The association between reflective functioning and parent-child relationship quality. J Child Fam Stud. 2016;25 (7):2164-77. [Link]

2. Babore A, Trumello C, Candelori C, Paciello M. \& Cerniglia L. Depressive symptoms, self-esteem and perceived parent-child relationship in early adolescence. Front Psychol, 2016; 7 (982). [Link]

3. Sanders MR. The Triple P-Positive Parenting Program: A public health approach to parenting support. Handbook of parent training: Helping parents prevent and solve problem behaviors. 2007:203-33. [Link]

4. Damodaran KD. Parent Child Interaction Therapy (PCIT): Child well-being through an effective parenting intervention. J Posit Psychol. 2015; 3: 1-12. [Link]

5. Ashori M, Afrouz G, Arjmandnia A, Pourmohammadreza-Tajrishi M, Ghobari-Bonab B. The Effectiveness of positive parenting program (Triple-P) training on interaction of mother-child with intellectual disability. Archives of Rehabilitation. 2015; 23 (5):489-500 [Persian]. [Link]

6. Ashori $M$, Ahmadiyan $Z$. Investigating the Effectiveness of Incredible Years' Program on the Interaction of Mother-Child with Behavioral Disorder. Quarterly of Psychology of Exceptional Individuals. Allameh Tabataba'i University 2018;8 (30):199-217. [Persian]. [Link]

7. Zablotsky B, Bradshaw CP, Stuart EA. The association between mental health, stress ,and coping supports in mothers of children with autism spectrum disorders. J Autism Dev Disord. 2013;43 (6):1380-93. [Link]

8. Heidary R, Isanejad O, yoosefi N. A Meta-Analysis on the Effectiveness of Parental Education Programs on Children Externalizing Disorder. JCR. 2019; 18 (70):35-58. [Persian]. [Link]

9. Sanders MR. Triple P-Positive Parenting Program: A population approach to promoting competent parenting. Australian e-journal for the Advancement of Mental Health. 2003;2 (3):127-143. [Link]

10. Khoshabi K, Ghadiri F, Gazayeri AR. The effect of parental management group training program appropriate to Iranian culture on reducing symptoms of Attention Deficit/Hyperactivity Disorder and comparing it with drug therapy. Journal of Family Research. 2006;2 (3):269-283.[Persian]. [Link]

11. Reed J, Byard K, Fine Hp. Neuropsychological Rehabilitation of Childhood Brain Injury. Zare H, sharifi AA., Mousavi Sh (Persian translator). Eige Publications; 2017. [Link]

12. Sanders M. Triple P: A multi-level system of parenting intervention: Workshop participant notes. The University of Queensland: Brisbane, Australia. 2005. [Link]

13. Sanders MR. Development, evaluation, and multinational dissemination of the Triple P-Positive Parenting Program. Annu Rev Clin Psychol. 2012;8:345-79. [Link]

14. Isanejad O, Xandan F. Comparing the effect of positive parenting program training (Triple $\mathrm{P}$ ) and parent management training (PMT) on parenting styles and emotional-behavioral problems in children. Journal of Counseling Research. 2017;16 (62):98-125. [Persian]. [Link]

15. Farshad MR, Najarpourian S, Shanbedi F. The Effectiveness of the Positive Parenting Education Based on Sanders' Approach on Happiness and Parent-Child Conflict of Students. Quarterly Journal of Child Mental Health. 2018;5 (1):59-67. [Persian]. [Link]

16. Kabiri A, kalantari M. The Effectiveness of Group Positive Parenting Program on Parental Stress and Mother-Child Interaction of Mother of Children with Nocturnal Enuresis. Journal of Knowledge \& Research in Applied Psychology. 2018; 19 (2): 115124. [Persian]. [Link]

17. Momeni Kh, Taziki T. The effectiveness of parentchild communication and parental stress Positive Parenting Program on students with attention deficit. Journal of Empowering Exceptional children. 2017; 8 (1):84-93. [Persian]. [Link]

18. Aslani Kh, Varasteh M, Amanelahi A. Effectiveness of positive parenting program training on parent-child interaction quality. Journal of Culture Counseling. 2017; 7 (28): 183-201. [Persian]. [Link]

19. Abedi Shapourabadi S, Pourmohamadreza Tajrishi M, Mohamadkhani P, Farzi M . The Effectiveness of Group Training Positive Parenting Program (Triple-P) on Symptoms of Children with Attention Deficit/Hyperactivity Disorder. J Rehabil. 2012;3 (15):63-73. [Persian]. [Link]

20. Ruane A, Carr A. Systematic Review and Metaanalysis of Stepping Stones Triple P for Parents of Children with Disabilities. Fam Process. 2019;58 (1):232-46. [Link]

21. Lohan A, Mitchell AE, Filus A, Sofronoff K, Morawska A. Positive parenting for healthy living (Triple P) for parents of children with type 1 diabetes: 
protocol of a randomised controlled trial. BMC Pediatr. 2016;16 (1):158. [Link]

22. Shirini Bonab M, Seyed Mousavi PS, Panaghi L. Comparison of the effect of child-parent relationship therapy (cprt) and parent management training (pmt) on nutritional problems in children 3 to 6 years. Quarterly Journal of Child Mental Health. 2020;6 (4):71-80. [Persian]. [Link]

23. Havighurst SS, Wilson KR, Harley AE, Kehoe C, Efron D, Prior MR. "Tuning into Kids": Reducing young children's behavior problems using an emotion coaching parenting program. Child Psychiatry \& Human Development. 2013;44 (2):247-64. [Link]

24. Forehand R, Lafko N, Parent J, Burt KB. Is parenting the mediator of change in behavioral parent training for externalizing problems of youth? Clin Psychol Rev. 2014;34 (8):608-19. [Link]

25. Kazdin AE. Parent management training: Treatment for oppositional, aggressive, and antisocial behavior in children and adolescents :Oxford University Press; 2008. [Link]

26. Ghasemi N, Nori L, Abdi Zarrin S. The Effect of Parent Management Training (PMT) on the Reduction of Behavioral Symptoms in Children with Attention Deficit Hyperactivity Disorder (ADHD). Quarterly Journal of Child Mental Health. 2019;6 (2):1-12. [Persian]. [Link]
27. Kaminski JW, Valle LA, Filene JH, Boyle CL. A meta-analytic review of components associated with parent training program effectiveness. J Abnorm Child Psychol. 2008;36 (4):567-89. [Link]

28. Shinn MM. Parent-child interaction therapy with a deaf and hard of hearing family. Clin Case Stud. 2013;12 (6):411-27. [Link]

29. Lees DG, Ronan KR. Engagement and effectiveness of parent management training (Incredible Years) for solo high-risk mothers: A multiple baseline evaluation. Behav Change. 2008;25 (2):109-128. [Link]

30. Shahim S, Yousefi F, A. S. Standardization and psychometric properties of Conner's Teacher Rating Scale form. Journal of Educational Sciences and Psychology, Shahid Chamran University of Ahvaz. 2007;14 (1,2):1-26. [Link]

31. Aliakbari Dehkordi MA, Kakojouibari AA, Mohtashami T, Yekdelehpour N. The effect of positive parenting program on parenting stress of mothers with impaired hearing children. Auditory and Vestibular Research. 2015;23 (6):66-75. [Persian]. [Link] 